OPEN ACCESS

Edited by:

Carlos F. O. Graeff

São Paulo State University, Brazi

Reviewed by:

Thomas Stergiopoulos,

Aristotle University of Thessaloniki,

Greece

Mirko Congiu,

São Paulo State University, Brazil

*Correspondence:

Simona Binett

simona.binetti@unimib.it

Specialty section:

This article was submitted to Physical Chemistry and Chemical

Physics,

a section of the journa

Frontiers in Chemistry

Received: 07 September 2018

Accepted: 11 April 2019

Published: 30 April 2019

Citation:

Le Donne A, Trifiletti $V$ and Binetti S (2019) New Earth-Abundant Thin Film

Solar Cells Based on Chalcogenides.

Front. Chem. 7:297.

doi: 10.3389/fchem.2019.00297

\section{New Earth-Abundant Thin Film Solar Cells Based on Chalcogenides}

\author{
Alessia Le Donne, Vanira Trifiletti and Simona Binetti* \\ Department of Materials Science and MIBSOLAR Center, University of Milano-Bicocca, Milan, Italy
}

At the end of 2017 roughly $1.8 \%$ of the worldwide electricity came from solar photovoltaics (PV), which is foreseen to have a key role in all major future energy scenarios with an installed capacity around 5 TW by 2050. Despite silicon solar cells currently rule the PV market, the extremely more versatile thin film-based devices (mainly $\mathrm{Cu}(\mathrm{In}, \mathrm{Ga}) \mathrm{Se}_{2}$ and $\mathrm{CdTe}$ ones) have almost matched them in performance and present room for improvement. The low availability of some elements in the present commercially available PV technologies and the recent strong fall of silicon module price below $1 \$ / W_{p}$ focused the attention of the scientific community on cheap earth-abundant materials. In this framework, thin film solar cells based on $\mathrm{Cu}_{2} \mathrm{ZnSnS}_{4}$ (CZTS) and the related sulfur selenium alloy $\mathrm{Cu}_{2} \mathrm{ZnSn}(\mathrm{S}, \mathrm{Se})_{4}$ (CZTSSe) were strongly investigated in the last 10 years. More recently, chalcogenide PV absorbers potentially able to face TW range applications better than CZTS and CZTSSe due to the higher abundance of their constituting elements are getting considerable attention. They are based on both $\mathrm{MY}_{2}$ (where $\mathrm{M}=\mathrm{Fe}, \mathrm{Cu}, \mathrm{Sn}$ and $Y=\mathrm{S}$ and/or $\mathrm{Se}$ ) and $\mathrm{Cu}_{2} \mathrm{XSnY}_{4}$ (where $X=\mathrm{Fe}, \mathrm{Mn}, \mathrm{Ni}, \mathrm{Ba}, \mathrm{Co}, \mathrm{Cd}$ and $Y=\mathrm{S}$ and/or Se) chalcogenides. In this work, an extensive review of emerging earth-abundant thin film solar cells based on both $\mathrm{MY}_{2}$ and $\mathrm{Cu}_{2} \mathrm{XSnY}_{4}$ species is given, along with some considerations on the abundance and annual production of their constituting elements.

Keywords: earth-abundant elements, binary chalcogenides, quaternary chalcogenides, low-cost solar cells, thin film PV

\section{INTRODUCTION}

In the last decades, the fast increase of the global energy demand and the progressive run-up in the world oil price, along with the growing global pollution strongly pointed out the need of an affordable and sustainable clean energy supply. As a matter of fact, the main energy sources since the Industrial Revolution were coal, oil, and natural gas, whose combustion is primarily blamed on the $\mathrm{CO}_{2}$ emission into the Earth's atmosphere responsible for many global climate changes. In order to face the 28 TW global energy demand foreseen for 2050 (Hoffert et al., 1998) without affecting the environment, a wider employment of renewable energies is therefore mandatory.

In the last 15 years, all renewable energies grew strongly in many end-use sectors (power, heating/cooling, and transport), in particular, at the end of 2017 , roughly $1.8 \%$ of the worldwide electricity came from solar photovoltaics (PV), which was the main source of new power capacity in many countries, including China, India, Japan, and United States. Globally, the newly installed capacity of solar PV in 2017 was around $98 \mathrm{GW}$ (about 29\% more than the record additions in 2016), which raised the cumulative total up to $402 \mathrm{GW}$ (REN21, 2018). In order to meet a noticeable portion of the global energy demand foreseen for 2050 (Hoffert et al., 1998), the installed capacity of solar PV will have to expand at least to $5 \mathrm{TW}$. However, almost all of the present commercially 
available PV technologies suffer from material or resource constraints that will likely limit their future role in TW scale applications. Currently, crystalline-Si (c-Si) based devices rule the solar PV market, accounting for about $94 \%$ of the total annual production vs. $6 \%$ for all alternative PV technologies (namely, thin-film CdTe, thin-film $\mathrm{Cu}(\mathrm{In}, \mathrm{Ga}) \mathrm{Se}_{2}$ (CIGS), and thin-film Si) (Fraunhofer ISE, 2017). The above mentioned limitations include the relevant energy amount required to fabricate c-Si solar cells and the low availability of one or more elements present in CdTe (i.e., Te), CIGS (i.e., In and Ga), c-Si and thin-film Si (i.e., Ag used as contact) PV devices (Tao et al., 2011) (see also Figure 1, USGS; WebElements). To overcome this problem, in the last 10 years thin films based on earth abundant elements were strongly investigated as PV absorbers, in particular, $\mathrm{Cu}_{2} \mathrm{ZnSnS}_{4}$ (CZTS) and the related sulfur selenium alloy $\mathrm{Cu}_{2} \mathrm{ZnSn}(\mathrm{S}, \mathrm{Se})_{4}$ (CZTSSe). CZTS and CZTSSe, in the stable crystalline kesterite form (tetragonal, space group I4, unit cell: $a$ $=5.427 \AA, c=10.871 \AA ; Z=2$ ), have direct bandgap around 1.5 and $1.1 \mathrm{eV}$, respectively, and high absorption coefficient (over $10^{4}$ $\mathrm{cm}^{-1}$ ) (Ito, 2014; Liu et al., 2016). They both showed promising performance, namely 9.2\% record efficiency for CZTS (Sun et al., 2016) and $12.6 \%$ for CZTSSe (Wang et al., 2014). Although there has been considerable progress in the performance of kesterite solar cells, further improvements are needed to achieve the high efficiency required for the practical application of these types of devices. First of all, the defects inside the material must be reduced to limit the recombination processes and the formation of band tail. But although several processes have been tested, such as the increase in doping and various treatments after deposition, still the defectiveness and the presence of deleterious secondary phases have not been sufficiently reduced. In fact, during the growth of CZTS films, given the complexity of the phase diagram, numerous secondary phases and intrinsic defects are produced. Complex and not yet fully understood are the relationships between growth process, chemical composition, and transport or recombination properties of photo-generated carriers. Moreover, the architecture of the most commonly used device is the same used for the realization of CIGS devices, although it is not actually optimized for kesterite (Ito, 2014). For example, the CdS/CZTS interface does not have an optimal band bending: an alternative layer would improve the charge transport and free the process of CZTS device realization from the use of cadmium (Santoni et al., 2013; Kumar et al., 2015). To overcome this problem, alternative buffer layers have been proposed, for instance $\mathrm{ZnCdS}$ (Congiu et al., 2018) and a $\mathrm{Zn}_{1-\mathrm{x}} \mathrm{Cd}_{\mathrm{x}} \mathrm{S}$ film that is able to optimize the conduction band offset, therefore diminishing the charge recombination (Sun et al., 2016).

As a matter of fact, a cheap PV technology requires both lowcost raw materials and low-cost production processes. As far as the cost of raw materials is concerned, elements with high abundance in the Earth's crust are good candidates for TW range PV applications, however both mining and processing of the minerals must be cheap as well. As an example, $\mathrm{Ga}$ is relatively abundant in the upper continental crust (roughly comparable to $\mathrm{Cu}, \mathrm{Ni}, \mathrm{Co}$, and $\mathrm{Sn}$ ) (WebElements), nevertheless producing 100 tons of Ga would imply in the best scenario the handling of 2,000,000 tons of bauxite (Tao, 2014), which makes Ga expensive.
Getting to the heart of the present matter, $\mathrm{Zn}$ is widely known as element under serious threat of extinction in the next 100 years (Harland et al., 2013), due to the combination of limited abundance in the earth crust, limited annual production and huge employment in many applications. As a consequence, in a TW scale PV scenario also CZTS will suffer from material or resource constraints, even if to a lower extent with respect to the present commercial PV devices. Therefore, CXTS absorbers based on significantly abundant elements must be developed and used along with CZTS to face the need of a 5 TW PV installed capacity by 2050 . As shown in Figure 1, Fe, Mn, Ni, Ba, Co, and $\mathrm{Cd}$ are good and/or possible alternatives to $\mathrm{Zn}$ in $\mathrm{Cu}_{2} \mathrm{XSn}(\mathrm{S}, \mathrm{Se})_{4}$ materials as well as $\mathrm{Cu}, \mathrm{Sn}$, and Fe are good candidates for $\mathrm{M}(\mathrm{S}$, $\mathrm{Se})_{2}$ chalcogenides, since they all show a convenient abundance to annual production ratio (USGS; WebElements). As far as the production cost is concerned, the development of cheap and easily scalable PV absorber layers strongly depends on growth techniques, which are usually classified as either vacuum or nonvacuum. About the vacuum methods, the sputtering technique is suitable to up-scaling the system in terms of active area and efficiency, while maintaining a good control of the deposition rate, while evaporation is one of the meritorious techniques to grow absorber layers without impurities. The non-vacuum methodologies, on the other hand, are lately attracting more and more attention in order to lower the production cost.

In this work, an extensive review of emerging earth-abundant thin film solar cells based on both $\mathrm{MY}_{2}$ and $\mathrm{Cu}_{2} \mathrm{XSnY}_{4}$ (where $M$ $=\mathrm{Fe}, \mathrm{Cu}, \mathrm{Sn} ; X=\mathrm{Fe}, \mathrm{Mn}, \mathrm{Ni}, \mathrm{Ba}, \mathrm{Co}, \mathrm{Cd} ; Y=\mathrm{S}$ and/or Se) species is given, along with some considerations on the abundance and annual production of their constituting elements.

\section{EARTH-ABUNDANT ELEMENTS FOR CHALCOGENIDE PV ABSORBERS}

\section{Iron}

Iron provides top abundance to annual production ratio, that is $63000 \mathrm{ppm}$ vs. $1.15 \times 10^{9}$ tons (USGS). Iron in fact makes up about $5 \%$ of the Earth's crust, being therefore the fourth most abundant element after oxygen, silicon and aluminum

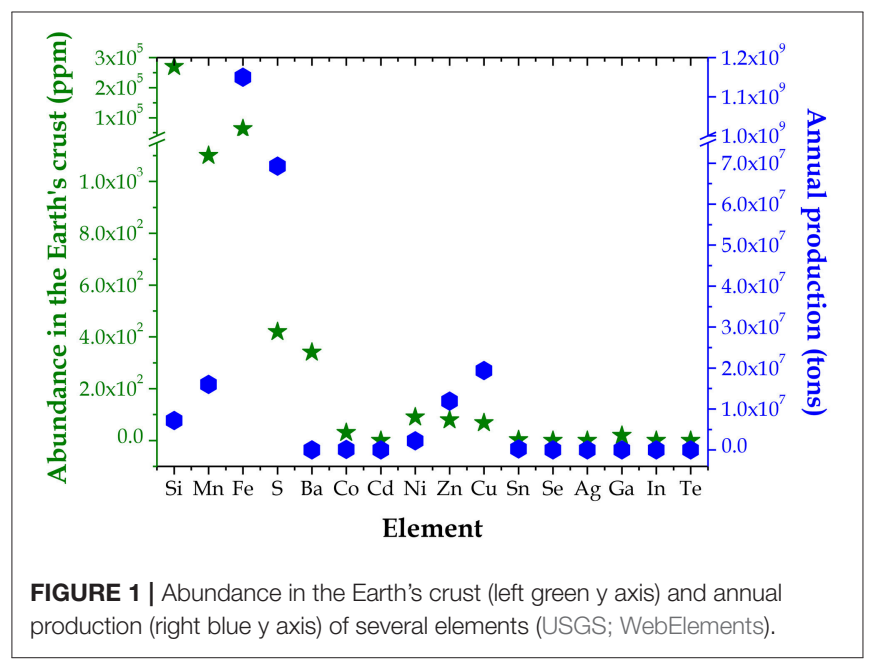


(WebElements). The iron is found in Nature mainly as iron oxide minerals such as siderite $\left(\mathrm{FeCO}_{3}\right)$, magnetite $\left(\mathrm{Fe}_{3} \mathrm{O}_{4}\right)$, and hematite $\left(\mathrm{Fe}_{2} \mathrm{O}_{3}\right)$. Moreover, the lower mantle of the Earth mainly consists of iron based compounds, that is ferropericlase ( $\mathrm{Mg}, \mathrm{Fe}) \mathrm{O}$ and silicate perovskite $(\mathrm{Mg}, \mathrm{Fe}) \mathrm{SiO}_{3}$ (Murakami et al., 2012). Industrial iron production uses iron ores, mainly magnetite and hematite, and it involves a carbothermic reaction to reduce the sources to the metal (Remus et al., 2013).

\section{Manganese}

Manganese is the 12th most abundant element, making up about $0.1 \%$ (1100 ppm) of the Earth's crust (WebElements). This value coupled with the high annual production of $1.6 \times 10^{7}$ tons (USGS) makes manganese a cheap element. Manganese occurs in the Earth's crust principally as pyrolusite $\left(\mathrm{MnO}_{2}\right)$, rhodochrosite $\left(\mathrm{MnCO}_{3}\right)$, psilomelane $\left(\mathrm{Ba}, \mathrm{H}_{2} \mathrm{O}\right)_{2} \mathrm{Mn}_{5} \mathrm{O}_{10}$, and braunite $\left(\left(\mathrm{SiO}_{4}\right) \mathrm{Mn}_{6} \mathrm{O}_{8}\right)$, the most important ore being pyrolusite (Bhattacharyya et al., 1984). In the 70s, it was estimated that the ocean floor had 500 billion tons of $\mathrm{Mn}$ nodules, however they were never exploited due to the absence of economically viable extraction methods (United Nations Ocean Economics Technology Office, 1978). Many manganese deposits are spread around the world, about $80 \%$ of them being located in South Africa. Other important producers are Ukraine, Australia, India, China, Gabon, and Brazil (Corathers, 2009). Pure $\mathrm{Mn}$ is produced by leaching manganese ore with sulfuric acid and subsequently employing an electrochemical process (Zhang and Cheng, 2007).

\section{Barium}

Barium is the 14th most abundant element in the Earth's crust making up a $0.0425 \%$ of it (340 ppm) (WebElements). The main commercial source of barium is barite $\left(\mathrm{BaSO}_{4}\right)$, a mineral with deposits in many parts of the world, principally in England, Romania, and Russian Federation (Kresse et al., 2007). The mined ores are washed, crushed, and separated from quartz. Barite with at least $95 \%$ purity undergoes a series of chemical reactions to produce pure $\mathrm{Ba}$. No precise estimations of the annual $\mathrm{Ba}$ production are available, which has few industrial applications. However, it is known that about $8 \times 10^{6}$ barite tons are annually produced (Kuck, 2012).

\section{Sulfur}

Sulfur is the 17th most common element in the Earth's crust (420 ppm) and generally the fifth most common on Earth (WebElements). Although it is also present on Earth in its pure, native form, sulfur usually occurs as sulfide and sulfate minerals, such as pyrite (iron sulfide), galena (lead sulfide), sphalerite (zinc sulfide), cinnabar (mercury sulfide), stibnite (antimony sulfide), alunite (potassium aluminum sulfate), gypsum (calcium sulfate), and barite (barium sulfate) (Anthony et al., 1990). Presently, elemental sulfur is mainly obtained as a byproduct of purifying natural gas and fossil fuels (Eow, 2002). Around 69'300'000 tons of sulfur are produced annually worldwide (USGS), which allows to fulfill the large sulfur demand related to its application in many fields.

\section{Nickel}

Nickel is the 24th most abundant element in the Earth's crust (80 ppm) (WebElements). The most important sources of nickel are limonite $\left(\mathrm{FeO}(\mathrm{OH}) \cdot n \mathrm{H}_{2} \mathrm{O}\right)$, pentlandite $\left((\mathrm{Fe}, \mathrm{Ni})_{9} \mathrm{~S}_{8}\right)$, and garnierite $\left(\mathrm{H}_{2} \mathrm{O}(\mathrm{Mg}, \mathrm{Ni})_{3} \mathrm{Si}_{4} \mathrm{O}_{10}(\mathrm{OH})_{2}\right)$ (Anthony et al., 1990). The world's largest nickel producers are Philippines, Indonesia, Russian Federation, Canada, and Australia (Kuck, 2012). Nickel is produced using ore by extractive metallurgy, employing conventional roasting and reduction processes which generate a metal with purity over 75\% (Nickel Institute). Around 2'250'000 tons of nickel are produced annually worldwide (USGS), however $\mathrm{Ni}$ is used in a plethora of applications: about $68 \%$ of world production for stainless steel, $9 \%$ for corrosion-resistant nickel plating, $10 \%$ for nickel and copper -based alloys, 7\% for alloy steels, $3 \%$ in foundries, and $4 \%$ in other applications, including the fast-growing battery sector (Nickel Institute).

\section{Elements With Limited Abundance in the Earth's Crust}

Zinc, copper, cobalt, tin, cadmium, silver and selenium are, respectively, the 25th (79 ppm), 26th (68 ppm), 32nd (30 ppm), 49th (2.2 ppm), 64th (0.15 ppm), 65th (0.08 ppm), and 67th (0.05 ppm) most abundant elements in the Earth's crust, with annual production around 12'000'000 tons, 19'400'000 tons, 123'000 tons, 280'000 tons, 23'000 tons, 27'000 tons, and 2'200 tons, respectively (USGS; WebElements). The abundance to annual production ratios of zinc, cobalt, cadmium, silver, and selenium and their large use in many sectors make them less suitable than the previously described elements for TW range PV applications. Conversely, the significant annual production of copper and tin, which may be properly recycled as well (Scott et al., 1997; Kasper et al., 2011), relieves their relatively limited abundance and accounts for the extensive research activity on $\mathrm{Cu}$ and $\mathrm{Sn}$ based alloys.

\section{EMERGING EARTH-ABUNDANT CHALCOGENIDE PV ABSORBERS}

\section{Binary Chalcogenides $\mathrm{FeS}_{2}$, $\mathrm{FeSe}$, and $\mathrm{FeSe}_{2}$}

Iron sulfide, $\mathrm{FeS}_{2}$ (iron(II) disulfide), is a mineral called pyrite, or iron pyrite, and also called fool's gold for its metallic luster and pale brass-yellow hue, that makes it looks like gold. Due to its abundance in nature and its low toxicity, $\mathrm{FeS}_{2}$ is a possible PV material. Its extraction cost is so low that a pyrite-based solar cell with only $4 \%$ efficiency could be as economical as a monocrystalline silicon solar cell with $20 \%$ efficiency (Wadia et al., 2009). Pyrite has a very high absorption coefficient $(\sim 5$ $\left.\times 10^{5} \mathrm{~cm}^{-1}\right)$ and an energy bandgap $\left(\mathrm{E}_{\mathrm{g}} \sim 0.95 \mathrm{eV}\right)$ suitable for converting PV energy. XRD pattern and Raman spectrum are reported in Figures $\mathbf{2 A}, \mathbf{B}$, respectively ${ }^{1}$. Various methods for the synthesis of thin films of pyrite have been adopted, such as $\mathrm{Fe}_{2} \mathrm{O}_{3}$ sulphuration, sputtering, spray pyrolysis (SP), vacuum evaporation (VE), chemical bath deposition (CBD), molecular

${ }^{1}$ RRUFF database. Available online at: http://rruff.info/chem=FeS/notchem=all/ display $=$ default $/ \mathrm{R} 100166$ 


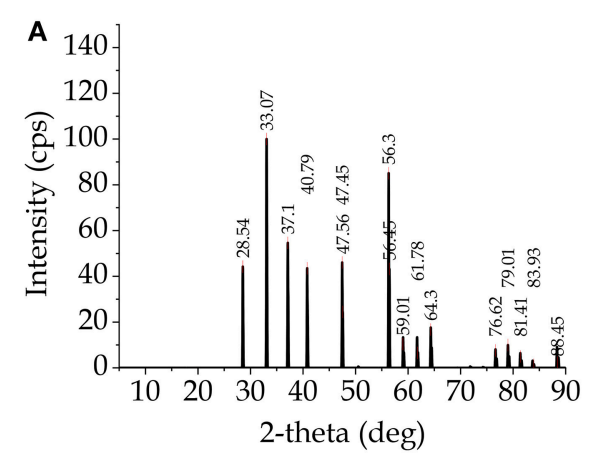

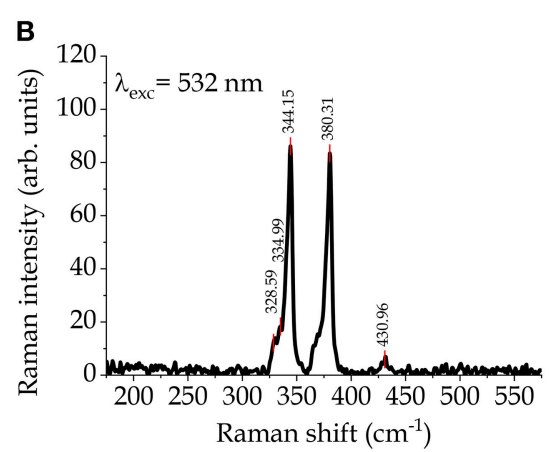

FIGURE 2 | (A) XRD pattern and (B) Raman spectrum of FeS 2 .

beam epitaxy (MBE), electrochemical deposition, and colloidal NC synthesis (Bi et al., 2011; Puthussery et al., 2011; Morrish et al., 2012; Bai et al., 2013; Prabukanthan et al., 2017).

$\mathrm{FeS}_{2}$ has a high potential in the large-scale production of PV modules, but for a long time, it was hard to obtain well workable thin-film devices that use pyrite as an absorber (Bi et al., 2011). Indeed, a significant PV efficiency value (8.39\%) (Huang et al., 2015) was obtained by using the $\mathrm{FeS}_{2}$ not as absorber material, but as a counter electrode in a DSC solar cell (Kilic and Turkdogan, 2017). The limiting factors are the high dark current, due to phase impurities, and a high density of acceptor surface states (Cabán-Acevedo et al., 2014). Moreover, $\mathrm{FeS}_{2}$ is affected by thermal instability (Yu et al., 2011). Lately, Prabukanthan et al. (2017) synthesized $\mathrm{FeS}_{2}$ thin films by electrochemical deposition at $70^{\circ} \mathrm{C}$ and reported efficiency of $1.98 \%$ for a solar cell with architecture $\mathrm{ITO} / \mathrm{FeS}_{2} / \mathrm{ZnSe} / \mathrm{Au}$ (PV parameters in Table 1). With the aim of enhancing the photoresponse and stabilize the structure, they have introduced 3 mole $\% \mathrm{Co}^{2+}$ as a dopant, reaching a remarkable efficiency of $5.42 \%$. They suggest that substituting $\mathrm{Co}^{2+}$ for $\mathrm{Fe}^{2+}$ makes the bandgap decrease, improving the charge separations at the interface with $\mathrm{ZnSe}$. Xray diffraction and Raman spectra confirmed that doped and undoped $\mathrm{FeS}_{2}$ thin films have a cubic pyrite structure; the atomic force microscopy revealed that the 3 mole $\%$ of $\mathrm{Co}^{2+}$ doped $\mathrm{FeS}_{2}$ thin film exhibits a smoother surface and lower roughness values (Prabukanthan et al., 2017).

Iron selenides can be found in two stoichiometric phases, FeSe and $\mathrm{FeSe}_{2}$. This last one, also called ferroselite, has been investigated as an electrode material in tandem PV; it is a p-type semiconductor material with a $1.0 \mathrm{eV}$ bandgap (Qurashi, 2014).

\section{CuS, $\mathrm{Cu}_{2} \mathrm{~S}$, and $\mathrm{Cu}_{2} \mathrm{Se}$}

Cuprous chalcogenide films, $\mathrm{CuS}, \mathrm{Cu}_{2} \mathrm{~S}, \mathrm{Cu}_{2} \mathrm{Se}$, are p-type semiconductors. They can be considered ideal materials for use in low-cost and non-toxic solar cells. $\mathrm{Cu}_{2} \mathrm{~S}$, for example, is an indirect gap semiconductor with a bandgap of $1.21 \mathrm{eV}$, which is optimal for use as a light absorber (Liu et al., 2003). Since the early 80 s, thin-film solar cells based on a $\mathrm{CdS} / \mathrm{Cu}_{2} \mathrm{~S}$ junction were produced, reaching efficiencies of $9.15 \%$, with open circuit voltage $\left(\mathrm{V}_{\mathrm{oc}}\right)$ of $516 \mathrm{mV}$, short circuit current density $\left(\mathrm{J}_{\mathrm{sc}}\right)$ equals to $19.3 \mathrm{~mA} / \mathrm{cm}^{2}$ and fill factor (FF) of $71.4 \%$ under a sunlight intensity of $87.9 \mathrm{~mW} / \mathrm{cm}^{2}$ (Bragagnolo et al., 1980). Subsequently, the research on these devices was abandoned due to the diffusion of $\mathrm{Cu}^{+}$in $\mathrm{CdS}$, to the high electron-hole recombination, and to the possibile coexistence of mixed phases ranging from $\mathrm{CuS}_{2}$, that has a metallic conduction (Munson et al., 1967), to $\mathrm{Cu}_{2} \mathrm{~S}$, which could give to the material a quasi-metallic behavior (Moitra and Deb, 1983; Niemegeers and Burgelman, 1986; Page et al., 2009). Nowadays, $\mathrm{Cu}_{2} \mathrm{~S}$ is successfully employed as sensitizer in DSCs: Mousavi-Kamazani et al. (2016) employed $\mathrm{Cu}_{2} \mathrm{~S}$ quantum dots as a barrier layer in DSCs, showing a considerable improvement in the efficiency of about $37 \%$. In thin film architecture, the last efforts are devoted to stabilizing the solar cells: Wu et al. (2008) presented the synthesis of colloidal $\mathrm{Cu}_{2} \mathrm{~S}$ nanocrystals and realized a solution-processed solar cell, coupled with CdS nanorods, with $1.6 \%$ efficiency and 4 months stability. $\mathrm{Cu}_{\mathrm{x}} \mathrm{S}$ shows at room temperature five stable phases, ranging from the more stable structure chalcocite $(x=$ $2)$, to the defective structure djurleite $(x=1.94)$, digenite $(x=$ $1.80)$, anilite $(x=1.75)$, and covellite $(x=1.00)$; mixed phases has been observed in the intermediate compositions. Congiu et al. (Congiu et al., 2016), have indeed proposed an ink-based method for realize $\mathrm{Cu}_{2-\mathrm{x}} \mathrm{S}$ counter electrode for DCS, showing high stability using ferrocene as redox shuttle. Various grown methods are reported: CBD (Loferski et al., 1979), successive ionic layer adsorption and reaction (SILAR) (Mani et al., 2014), MBE (Gautier et al., 1998), VE (Nair et al., 1998), solid state reaction (Sanchez Ranjel et al., 2015), SP (Sabah et al., 2015), hydrothermal method (Patil et al., 2018), atomic layer deposition (ALD), and chemical vapor deposition (CVD) (Ye et al., 2015). $\mathrm{CuS}$ is 2D metal chalcogenide (Karthick Kannan et al., 2015) mostly employed as a hole transport material in solar cells, rather than as a light absorber (Lei et al., 2014; Rao et al., 2016), and thanks to the high catalytic activity, proved to guarantee high performing DSCs (Li et al., 2014; Zhang et al., 2016a,b).

Copper selenides exist in many phases and structural forms, such as $\mathrm{CuSe}$ (klockmannite), $\mathrm{Cu}_{2} \mathrm{Se}_{\mathrm{x}}, \mathrm{CuSe}_{2}$ (marcasite), $\alpha$ $\mathrm{Cu}_{2} \mathrm{Se}$ (bellidoite), $\mathrm{Cu}_{3} \mathrm{Se}_{2}$ (umagnite), $\mathrm{Cu}_{5} \mathrm{Se}_{4}$ (athabaskite), $\mathrm{Cu}_{7} \mathrm{Se}_{4}$, and in isometric form as $\mathrm{Cu}_{2-\mathrm{x}} \mathrm{Se}$ (berzelianite). They may also have different crystallographic forms (monoclinic, cubic, tetragonal, hexagonal, etc.). Copper selenides are $\mathrm{p}$ type semiconductors, with both direct and indirect bandgap 


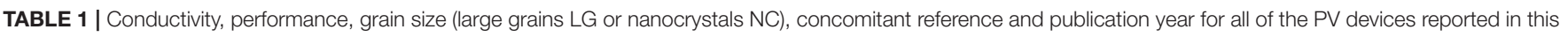
work.

\begin{tabular}{|c|c|c|c|c|c|c|c|}
\hline Material & Conductivity & Efficiency (\%) & $V_{\text {oc }}(\mathrm{V})$ & $\mathrm{J}_{\mathrm{sc}}\left(\mathrm{mA} / \mathrm{cm}^{2}\right)$ & FF (\%) & Grain size & References \\
\hline $\mathrm{FeS}_{2}$ & p-type & 1.98 & 0.57 & 6.55 & 53 & $\mathrm{NC}$ & Prabukanthan et al., 2017 \\
\hline $\mathrm{Co}^{2+}(3 \% \mathrm{~mol})$ doped $\mathrm{FeS}_{2}$ & p-type & 5.42 & 0.83 & 10.71 & 61 & $\mathrm{NC}$ & Prabukanthan et al., 2017 \\
\hline $\mathrm{Cu}_{2} \mathrm{~S}$ & p-type & 9.15 & 0.52 & 19.3 & 71.4 & LG & Bragagnolo et al., 1980 \\
\hline $\mathrm{Cu}_{2} \mathrm{~S}$ & p-type & 1.6 & 0.57 & 5.625 & 49.4 & $\mathrm{NC}$ & Wu et al., 2008 \\
\hline SnS & p-type & 4.4 & 0.372 & 20.2 & 58 & LG & Sinsermsuksakul et al., 2014 \\
\hline heterostructure $\mathrm{SnS} / \mathrm{SnS}_{2}$ & p-type/n-type & 0.51 & 0.12 & 10.87 & 39 & LG & Gedi et al., 2016 \\
\hline heterostructure $\mathrm{SnS} / \mathrm{SnS}_{2}$ & p-type/n-type & 1.4 & 0.53 & 5.7 & 46.5 & NC & Degrauw et al., 2017 \\
\hline SnSe & p-type & 1.42 & 0.299 & 11.6 & 41 & LG & Minnam Reddy et al., 2018 \\
\hline CFTS & p-type & 2.95 & 0.61 & 9.3 & 52 & $\mathrm{NC}$ & Chatterjee and Pal, 2017 \\
\hline CFTS & p-type & 0.11 & 0.13 & 3.25 & 26.6 & LG & Meng et al., 2016 \\
\hline CMTS & p-type & 0.49 & 0.308 & 4.7 & 33.9 & LG & Chen et al., 2015b \\
\hline CMTS & p-type & 0.38 & 0.359 & 2.95 & 35.8 & LG & Chen et al., 2016a \\
\hline CMTS & p-type & 0.73 & 0.381 & 4.95 & 38.6 & LG & Prabhakar et al., 2016 \\
\hline CMTS & p-type & 0.33 & 0.23 & 4 & 36.3 & LG & Marchionna et al., 2017 \\
\hline CMTS & p-type & 0.83 & 0.35 & 5.8 & 40 & LG & Le Donne et al., 2017 \\
\hline CBTS & p-type & 1.54 & 0.699 & 4.1 & 53.5 & LG & Shin et al., 2016 \\
\hline CBTS & p-type & 5.2 & 0.611 & 17.4 & 48.9 & LG & Shin et al., 2017 \\
\hline CBTSSe & p-type & 1.57 & 0.613 & 6.78 & 37.7 & LG & Ge et al., 2016 \\
\hline CCdTS & p-type & 2.7 & 0.513 & 12.7 & 42 & LG & Timmo et al., 2013 \\
\hline CCdTSSe & p-type & 3.1 & 0.356 & 20.89 & 41.6 & LG & Zhao et al., 2015 \\
\hline AZTSe & n-type & 5 & 0.5 & 22 & 49 & LG & Gershon et al., 2016a \\
\hline$\left(\mathrm{Ag}_{x} \mathrm{Cu}_{1-\mathrm{x}}\right)_{2} \mathrm{ZnSnSe} 4$ & p-type & 10.2 & 0.423 & 38.4 & 62.9 & LG & Gershon et al., 2016b \\
\hline
\end{tabular}

(Petrović et al., 2017), which may be potentially employed as PV absorbers. CuSe at room temperature has a hexagonal structure and undergoes an orthorhombic transition at $48^{\circ} \mathrm{C}$ and a hexagonal transition at $120^{\circ} \mathrm{C}$. At higher temperatures, CuSe decomposes into $\mathrm{Cu}_{2-x} \mathrm{Se}$ and selenium. $\mathrm{Cu}_{2-\mathrm{x}} \mathrm{Se}$, at room temperature, has a cubic structure with faces centered with 0.15 $\leq \times \leq 0.2$ and; when $x=0.2$, it shows a direct bandgap of $2.2 \mathrm{eV}$ and an indirect bandwidth of 1.4 eV (Qurashi, 2014).

\section{SnS and SnSe}

Tin can form sulfides with different $\mathrm{Sn} / \mathrm{S}$ ratio, such as: $\mathrm{SnS}_{2}$, $\mathrm{Sn}_{2} \mathrm{~S}_{3}, \mathrm{Sn}_{3} \mathrm{~S}_{4}, \mathrm{Sn}_{4} \mathrm{~S}_{5}, \mathrm{SnS}$ (Jiang and Ozin, 1998). The most investigated are tin(II) sulfide ( $\mathrm{SnS}$ ), with a distorted GeS structure and $\operatorname{tin}(\mathrm{IV})$ sulfide $\left(\mathrm{SnS}_{2}\right)$ with a $\mathrm{PbI}_{2}$ structure (Rimmington et al., 1972). Tin(IV) sulfide can be found in 70 polytype structures, with a hexagonal close-packed structure and different c parameters (Pałosz et al., 1990). Tin monosulphide $(\mathrm{SnS})$ is a mineral called herzenbergite, and the synthesized SnS is a p-type semiconductor material, as the tin vacancies generate acceptor levels (Thangaraju and Kaliannan, 2000). Figure 3 shows the XRD pattern (a) and the Raman spectrum (b) for single-crystal SnS (Raadik et al., 2013).

When then tin to sulfur ratio is $\mathrm{SnS}_{0.8}$, it has a bandgap of $1.16 \mathrm{eV}$ (Price et al., 1999), which is like that of silicon, but with a higher optical absorption coefficient. Although the maximum theoretical efficiency of SnS thin-film solar cells is 32\%, the maximum efficiency is $4.4 \%$, reported by Sinsermsuksakul et al. (2014). They deposited, by ALD, SnS films (400 nm), using alternating doses of tin precursor vapor and a gas mixture of $4 \%$ $\mathrm{H}_{2} \mathrm{~S}$ in $\mathrm{N}_{2}$, to enlarge the grains and reduce the recombination at the boundaries. Additionally, they engineered the n-type $\mathrm{Zn}(\mathrm{O}, \mathrm{S})$ buffer layer $(30 \mathrm{~nm})$, reducing the sulfur and adding nitrogen as a dopant, to improve the rectifying quality of the $p-n$ junction, and introduced a $1 \mathrm{~nm}$ thick $\mathrm{SnO}_{2}$, to enhance the quality of the $\operatorname{SnS} / \mathrm{Zn}(\mathrm{O}, \mathrm{S})$ interface (Sinsermsuksakul et al., 2014). The low solar cells performance can be due also to phase impurity and off-stoichiometry (Sinsermsuksakul et al., 2014). Kim and coworkers (Kim et al., 2018) investigated the presence of Sn$S$ polytypes $\left(\mathrm{SnS}, \mathrm{SnS}_{2}, \mathrm{Sn}_{2} \mathrm{~S}_{3}\right.$ ) and their effect on the solar cells performance. $\mathrm{SnS}$ requires high sulfurization temperature, $500^{\circ} \mathrm{C}$, meanwhile, the transition to $\mathrm{SnS}_{2}$ and $\mathrm{Sn}_{2} \mathrm{~S}_{3}$ happens between 150 and $300^{\circ} \mathrm{C}$ (Banu et al., 2017). Unfortunately, $\mathrm{SnS}_{2}$ shows n-type conductivity and its presence affects the open circuit voltage. $\mathrm{Sn}_{2} \mathrm{~S}_{3}$ has an energy gap of $1.09 \mathrm{eV}$, like the of $\mathrm{SnS}$ one, but a phase mixture can influence the carrier transport, generating a type II junction between $\mathrm{Sn}_{2} \mathrm{~S}_{3}$ and $\mathrm{SnS}$ (Burton et al., 2013). Kim et al. (2018) did not verify the presence of $S_{2} S_{3}$, but they found out that the $\mathrm{SnS}_{2}$ phase can be predominant on the thin film surface and in the shallow bulk area. Therefore, another key point is the selection of an adequate buffer layer for the SnS absorber: lately, many researchers are focused on the realization of $\mathrm{SnS} / \mathrm{SnS}_{2} \mathrm{p}-\mathrm{n}$ junction, with the aim to improve the SnS/buffer interface. Firstly, Sanchez-Juarez et al. (2005) fabricated an $\mathrm{SnS} / \mathrm{SnS}_{2}$ thin film hetero-junction by plasmaenhanced chemical vapor deposition, verifying the PV effect. More recently, Gedi et al. (2016) fabricated $\mathrm{SnS} / \mathrm{SnS}_{2}$ solar cells 

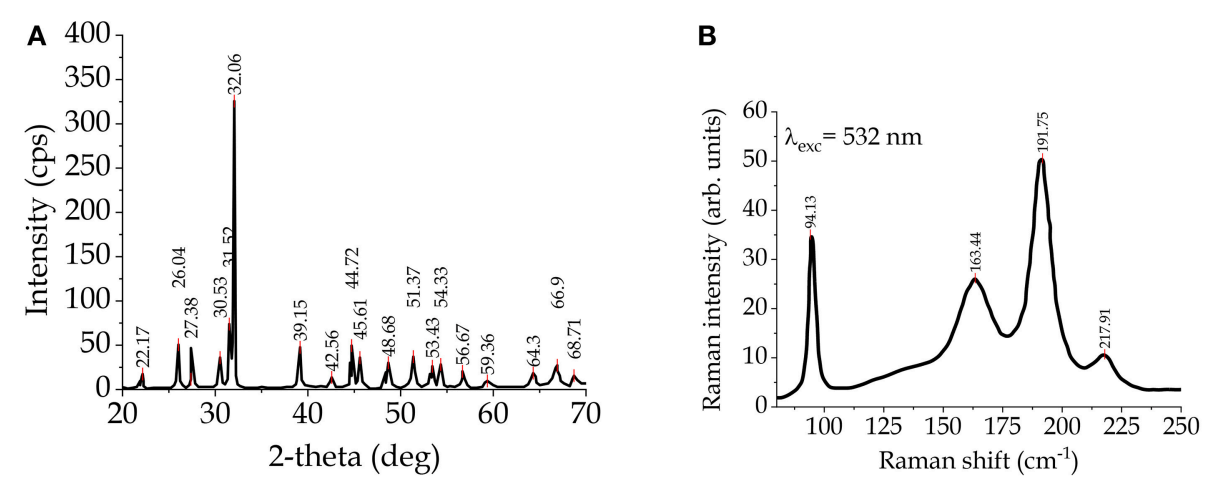

FIGURE 3 | (A) XRD pattern and (B) Raman spectrum of SnS.

by $\mathrm{CBD}$, the efficiency of $0.51 \%$, proving that the junction is a type-II heterostructure. Degrauw et al. (2017) grown nanowire arrays of $\mathrm{SnS} / \mathrm{SnS}_{2}$ heterojunction, by chemical vapor transport (CVT) catalyzed by $\mathrm{Cu}$ particles, and fabricated devices with the efficiency of $1.4 \%$.

Tin and selenium form tin(II) selenide (SnSe), also called stannous selenide, which is a p-type semiconductor, with both an indirect bandgap at $0.90 \mathrm{eV}$ and a direct bandgap at $1.30 \mathrm{eV}$ (Lefebvre et al., 1998). It is receiving increasing attention for potential applications in low-cost PV, as it is an easy processable two-dimensional layered material (Wang et al., 2016; Jeong et al., 2017; Razykov et al., 2018; Ul Haq et al., 2018). fabricated SnSe thin films by chemical molecular beam deposition, using synthesized polycrystalline SnSe as precursors: XRD analysis proves that SnSe films can be grown in the orthorhombic crystalline structure. The realized films displays a direct optical bandgap of $1.1-1.2 \mathrm{eV}$ and a remarkable high absorption coefficient of about $10^{5} \mathrm{~cm}^{-1}$. The authors have proven that the physical properties of SnSe thin films are strongly affected by the growth conditions, and that a proper develop of the deposition methodology can lead to a material suitable for thin film solar cells. Lately Minnam Reddy et al. (2018), have fabricated a SnSe solar cells a power conversation efficiency of $1.42 \%$.

\section{Quaternary Chalcogenides $\mathrm{Cu}_{2} \mathrm{FeSnS}_{4}$}

As mentioned above, iron shows top abundance to annual production ratio, therefore p-type $\mathrm{Cu}_{2} \mathrm{FeSnS}_{4}$ (CFTS) is a very good candidate as cheap chalcogenide $\mathrm{PV}$ absorber layer. In addition, CFTS shows bandgap $(1.28-1.50 \mathrm{eV})$ and absorption coefficient $\left(>10^{4} \mathrm{~cm}^{-1}\right)$ suitable for PV applications.

The crystal structure of CFTS, which is a lustrous dark gray mineral, is basically stannite, however early X-ray diffraction (XRD) studies demonstrated that the tetragonal stannite phase I $(-42 \mathrm{~m})$ is stable in the temperature range between 420 and $500^{\circ} \mathrm{C}$ (Quintero et al., 1999). At higher temperature, cubic polymorphous modifications with disordered sphaleritelike structure I $(-43 \mathrm{~m})$ were also observed (Evstigneeva and Kabalov, 2001). XRD pattern and Raman spectrum (widely used for the identification of possible secondary phases in the fabricated films) of typical stannite $\mathrm{CFTS}^{2}$ are depicted in Figures 4A,B, respectively.

So far, various methods have been reported for the preparation of CFTS absorber layers (Guan et al., 2014; Kevin et al., 2015; Khadka and Kim, 2015; Meng et al., 2015a, 2016; Chatterjee and Pal, 2017; Chen et al., 2017; Miao et al., 2017). Most of them are based on non-vacuum techniques, since they are simple, low-cost, often efficient and do not require sophisticated deposition set-up. Very few efficiency values were reported up to now for CFTS based PV devices, the best one being recently obtained by Chatterjee and Pal (2017) through SILAR method. SILAR is a low temperature non-vacuum technique, which offers a good balance between fabrication cost and phase purity, while being easily scalable for large area depositions. The asformed CFTS thin films prepared in Chatterjee and Pal (2017) showed stannite structure with high crystallinity and a lower limit of crystallite size around $10 \mathrm{~nm}$, as confirmed by XRD, Scanning Electron Microscopy (SEM), and cross-sectional SEM. The optical bandgap calculated through the Tauc's plot obtained from transmittance measurements was $1.5 \mathrm{eV}$, in agreement with the literature. Several n-type semiconductors were considered to complete the heterojunction, all of them obtained by SILAR as well. The best conversion efficiency of $2.95 \%$ was achieved with promising reproducibility in CFTS/ $\mathrm{Bi}_{2} \mathrm{~S}_{3}$ heterojunctions (Chatterjee and Pal, 2017). Meng et al. (2015a, 2016) also reported PV device efficiencies, obtained by solar cells based on CFTS prepared by sulfurization of the sputtered metal precursors. They showed that CFTS thin films sulfurized under fast heating rate around $40^{\circ} \mathrm{C} / \mathrm{min}$ were S-poor and showed a bilayer structure with many micro-grains at the bottom of the CFTS thin film. By reducing the heating rate to $20^{\circ} \mathrm{C} / \mathrm{min}$, CFTS isolated grains were formed and the in general the grain size increases, most probably since a lower heating rate gives enough time and energy to favor the precursor crystallization and alloying. The best sputtering based CFTS solar cell prepared in Meng et al. (2016) showed a $0.11 \%$ efficiency $\left(\mathrm{V}_{\mathrm{oc}}=129 \mathrm{mV}, \mathrm{J}_{\mathrm{sc}}=3.25 \mathrm{~mA} / \mathrm{cm}^{2}, \mathrm{FF}=26.6 \%\right)$. ${ }^{2}$ RRUFF database. Available online at: http://rruff.info/chem=Cu\%20Fe\%20Sn
$\% 20$ S/display=default/R050187 


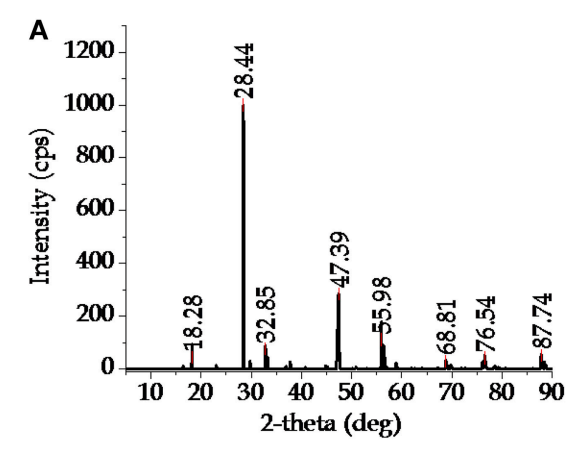

FIGURE 4 | (A) XRD pattern and (B) Raman spectrum of typical stannite CFTS

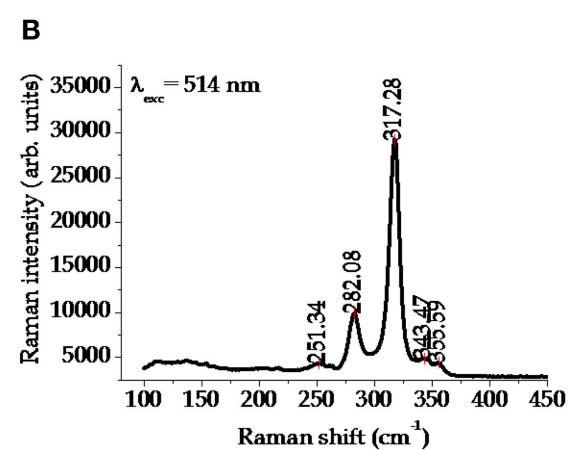

Guan et al. (2014) reported for the first time on the preparation of CFTS thin films by the SILAR method, obtaining CFTS layers with large agglomeration of rod-shaped grains, a bandgap of $1.22 \mathrm{eV}$ and an absorption coefficient higher than $10^{4} \mathrm{~cm}^{-1}$. Khadka and Kim (Khadka and Kim, 2015) employed electrostatic field assisted spray pyrolysis followed by sulfurization to produce stannite structured CFTS and CFTSe. Both the structural quality (i.e., crystalline texture and grain size) and the carrier mobility of CFTS/CFTSe thin films improved after the sulfur addition. Kevin et al. (2015) reported on CFTS, CFTSe, and CFTSSe thin films deposited by Aerosol Assisted Chemical Vapor Deposition (AACVD) at $350^{\circ} \mathrm{C}$ using mixtures of molecular precursors. More recently, CFTS thin films were prepared by doctor blade deposition of oxides $\left(\mathrm{CuO}, \mathrm{Fe}_{2} \mathrm{O}_{3}\right.$, and $\left.\mathrm{SnO}_{2}\right)$ on glass followed by sulfurization (Chen et al., 2017) and by electrochemical deposition followed by annealing at $500-550^{\circ} \mathrm{C}$ (Miao et al., 2017).

Incidentally, beside its role as low-cost photo-absorber layer in thin film solar cells, CFTS was recently considered both as counter electrodes and as cheaper alternative to platinum (Pt) in dye sensitized solar cells. An extensive review on these topics is reported in Vanalakara et al. (2018).

\section{$\mathrm{Cu}_{2} \mathrm{MnSnS}_{4}$}

As mentioned above, $\mathrm{Mn}$ provides relevant abundance to annual production ratio, therefore p-type $\mathrm{Cu}_{2} \mathrm{MnSnS}_{4}$ (CMTS) is also a good candidate as cheap chalcogenide PV absorber layer. CMTS was investigated above all as single crystal (Podsiadlo et al., 2015) or nanocrystal (Cui et al., 2012; Liang et al., 2012) for the diluted magnetic semiconductor characteristic, while, in the last few years, some papers reported on CMTS thin films for PV applications (Chen et al., 2015a,b, 2016a; Wang et al., 2015; Prabhakar et al., 2016; Le Donne et al., 2017; Marchionna et al., 2017; Yu et al., 2017). Wang et al. (2015) obtained stannite CMTS thin films by sulfurization of different precursor $(\mathrm{Cu}, \mathrm{Sn}) \mathrm{S} / \mathrm{MnS}$ and $(\mathrm{Cu}, \mathrm{Sn}, \mathrm{Mn}) \mathrm{S}$ films, all deposited on glass by chemical methods. The surface morphologies basically consisted of small and irregular crystalline grains (size around $18-22 \mathrm{~nm}$ ) with a few voids. The optical bandgap values ranged between 1.15 and $1.26 \mathrm{eV}$, while the occurrence of a p-type conductivity was confirmed. Chen et al. (2015a) reported on the synthesis and the properties of stannite CMTS thin films grown by direct liquid coating and by annealing in nitrogen atmosphere, which were employed in Chen et al. (2015b) as photo-absorbers in solar cells achieving $0.49 \%$ of maximum efficiency. Some of the same authors showed also that CMTS thin films can be prepared by direct liquid coating and combining the annealing in nitrogen atmosphere and the post-sulfurization in sulfur vapors, reporting a $0.38 \%$ efficiency (Chen et al., 2016a). The same group recently investigated CMTS thin films grown by sulfurization of electrodeposited $\mathrm{Cu}-\mathrm{Sn} / \mathrm{Mn}$ metal precursors (Yu et al., 2017), which are a promising starting point for the preparation of CMTS layers by a simple, environmentally friendly and low-cost method. Prabhakar et al. (2016) presented a study on thin film solar cells based on stannite CMTS and $\mathrm{Cu}_{2} \mathrm{MnSn}(\mathrm{S}, \mathrm{Se})_{4}$ (CMTSSe) layers, fabricated by spray pyrolysis using water as solvent. Proof-of-concept PV devices with structure Mo/CMTS/CdS/TCO provided the best performance (i.e., $0.73 \%$ efficiency) when CMTS layers were doped with $\mathrm{Na}$ in the form of $\mathrm{NaCl}$ during the spray process. $\mathrm{Na}$ in fact is widely known to improve grain growth and reduce non-radiative recombination both in CIGS and CZTS thin films. Through a careful electrical analysis (Hall measurements on exfoliated films and J-V curves under illumination of the PV devices), a very high carrier density in the CMTS/CMTSSe layers was identified as responsible for the low $\mathrm{V}_{\text {oc }}$ and FF values.

Some of the present authors reported on CMTS PV absorber synthesized by a two-step process: firstly the metal precursor stacks have been deposited by thermal evaporation, and then they have been annealed in nontoxic sulfur vapors (Le Donne et al., 2017; Marchionna et al., 2017). Of the many possible stoichiometries, Cu-poor/Mn-rich CMTS films with $\mathrm{Mn} / \mathrm{Sn}$ ratio around 1 were chosen to avoid the arise of both highly conductive (e.g., $\mathrm{Cu}_{2-\mathrm{x}} \mathrm{S}$ ) and insulating (e.g., $\mathrm{MnS}$ ) secondary phases. In (Marchionna et al., 2017), an extensive characterization of both CMTS and any possible secondary phases by SEM, Energy Dispersive Spectroscopy, Raman, XRD, and Photoluminescence (PL) was presented. Large grain size (see Figure 5), direct band suitable for PV applications and high absorption coefficient have been reported for $\mathrm{Cu}$-poor/Mn-rich samples synthesized by sulfurization with temperatures between 500 and $585^{\circ} \mathrm{C}$, starting the annealing process at $115^{\circ} \mathrm{C}$ to trigger the alloy formation. 

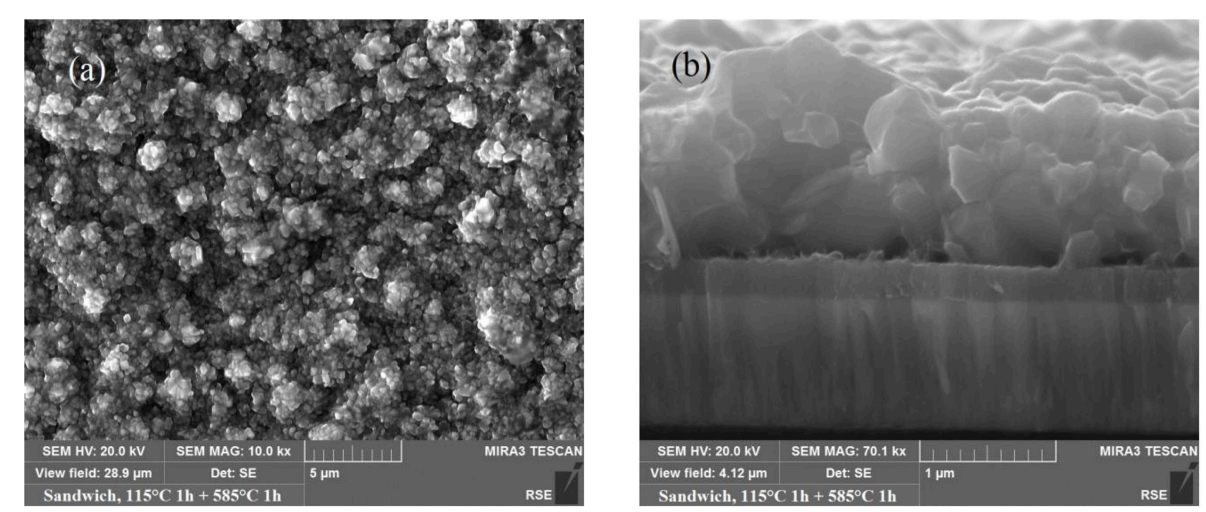

FIGURE 5 | (a) SEM image of CMTS samples grown by sulfurization at $115+585^{\circ} \mathrm{C}$; (b) cross sectional SEM image of a CMTS sample grown by sulfurization at 115 $+585^{\circ} \mathrm{C}$ [Reprinted from (Marchionna et al., 2017) with copyright permission from Elsevier].

Limited electrical performance were reached (efficiency $0.33 \%$, $\mathrm{V}_{\mathrm{oc}}=226 \mathrm{mV}, \mathrm{J}_{\mathrm{sc}}=4 \mathrm{~mA} / \mathrm{cm}^{2}$, FF 36.3\%) (Marchionna et al., 2017), mainly due to the presence of $\mathrm{Cu}_{7.38(11)} \mathrm{Mn}_{4} \mathrm{Sn}_{12} \mathrm{~S}_{32}$, a spinel-type insulating secondary phase.

$\mathrm{Cu}$-poor/Mn-rich CMTS layers with better homogeneity of the metal ratios were presented in Le Donne et al. (2017), reached through an enhanced control of the precursor evaporation rate; PV devices showed improved performance compared to (Marchionna et al., 2017): efficiency 0.5 vs, $0.33 \%, \mathrm{~V}_{\text {oc }}=$ 302 vs, $226 \mathrm{mV}, \mathrm{J}_{\mathrm{sc}}=4.6$ vs. $4 \mathrm{~mA} / \mathrm{cm}^{2}$, FF 36 vs. $36.3 \%$. Considering the beneficial consequences of low temperature post-deposition thermal treatments on kesterite based solar cells (Neuschitzer et al., 2015; Jiang et al., 2016), the effect of annealing temperature ranging from 200 to $275^{\circ} \mathrm{C}$ on the same CMTS devices was investigated, too. The best annealing in air at $225^{\circ} \mathrm{C}$ for $40 \mathrm{~min}$ led to a significant reduction of recombination losses without a strong increase of CdS absorption, allowing for a remarkable improvement of CMTS solar cell performance $\left(\mathrm{J}_{\mathrm{sc}}=5.8 \mathrm{~mA} / \mathrm{cm}^{2}\right.$, FF $40 \%, \mathrm{~V}_{\mathrm{oc}}=354 \mathrm{mV}$, efficiency $\left.0.83 \%\right)$ (Le Donne et al., 2017).

\section{$\mathrm{Cu}_{2} \mathrm{BaSnS}_{4} / \mathrm{Cu}_{2} \mathrm{BaSn}(\mathrm{S}, \mathrm{Se})_{4}$}

As it is known in the literature, $\mathrm{V}_{\mathrm{oc}}$ in CZTS/CZTSSe is mainly limited by the band tailing related to cation-cation antisite disorder and by the following potential fluctuations (Gokmen et al., 2013). The main antisite defects, responsible of the antisite disorder, are copper-on-zinc $\left(\mathrm{Cu}_{\mathrm{Zn}}\right)$ and zinc-on-copper $\left(\mathrm{Zn}_{\mathrm{Cu}}\right)$ (Chen et al., 2013). Furthermore, Sn multivalency could induce deep levels in the bandgap, which in turn could cause non-radiative recombination, when $\mathrm{Sn}^{2+}$ occupies a $\mathrm{Zn}^{2+}$ site (Chen et al., 2013). Thanks to the distinct electronic properties exhibited by $\mathrm{Cu}, \mathrm{Sn}$ and $\mathrm{Ba}$, the formation of cation-cation antisite defects in $\mathrm{Cu}_{2} \mathrm{BaSnS}_{4}$ (CBTS)/Cu $\mathrm{Cu}_{2} \mathrm{BaSn}(\mathrm{S}, \mathrm{Se})_{4}$ (CBTSSe) has been proven to be difficult (Xiao et al., 2017). Therefore, in addition to the good abundance to annual production ratio provided by $\mathrm{Ba}, \mathrm{CBTS} / \mathrm{CBTSSe}$ could potentially lead to better optoelectronic properties than CZTS/CZTSSe. Up to now, very few works reported on CBTS/CBTSSe, which mainly deal with vacuum deposition methods (Ge et al., 2016; Shin et al., 2016, 2017). Shin et al. investigated $\mathrm{Cu}_{2} \mathrm{BaSnSe}_{\mathrm{x}} \mathrm{S}_{4-\mathrm{x}}$ films with different Se contents prepared by co-sputtering followed by sulfurization/selenization (Shin et al., 2016). Of the different examined stoichiometries, combined experimental and theoretical analyses showed that $\mathrm{Cu}_{2} \mathrm{BaSnSe}_{\mathrm{x}} \mathrm{S}_{4-\mathrm{x}}$ thin films with $0<\mathrm{x} \leq 3$ compositions are isostructural to CBTS with space group $\mathrm{P} 3_{1}$ and display a tunable bandgap in the $1.6-2 \mathrm{eV}$ range, which well fits the optimal values for being employed both in single junction (i.e., $1-1.6 \mathrm{eV}$ ) and top solar cell in multijunction (i.e., 1.7-2.0 eV) PV devices. Furthermore, optical absorption, External Quantum Efficiency and PL data confirmed the expected absence of band tailing in CBTS. Last but not least, prototype CBTS-based thin-film solar cells with $1.54 \%$ average efficiency have been prepared and tested $\left(\mathrm{V}_{\mathrm{oc}}=699 \mathrm{mV}\right.$, $\mathrm{J}_{\mathrm{sc}}=4.1 \mathrm{~mA} / \mathrm{cm}^{2}, \mathrm{FF}=53.5 \%$ ) (Shin et al., 2016). Some of the same authors obtained further improvements by combining the bandgap tuning related to the introduction of Se with a post-deposition annealing in air, producing a CBTSSe-based PV device with 5.2\% efficiency (Shin et al., 2017). Ge et al. (2016) studied polycrystalline $\mathrm{Cu}_{2} \mathrm{BaSn}\left(\mathrm{Se}_{0.83} \mathrm{~S}_{0.17}\right)_{4}$ (CBTSSe) thin films grown on fluorine tin oxide (FTO) by co-sputtering of a sulfide precursor followed by selenization. In contrast to the XRD results reported in (Shin et al., 2016), these layers (Ge et al., 2016) are isostructural to CBTSe with space group Ama2. Conversely, they exhibit, as expected, an optical bandgap around $1.85 \mathrm{eV}$, absorption coefficient higher than $10^{4} \mathrm{~cm}^{-1}$, and p-type conductivity. A proof-of-concept PV device with FTO/BCTSSe/CdS/ZnO/AZO structure showed $1.57 \%$ efficiency $\left(\mathrm{V}_{\mathrm{oc}}=613 \mathrm{mV}, \mathrm{J}_{\mathrm{sc}}=6.78 \mathrm{~mA} / \mathrm{cm}^{2}, \mathrm{FF}=37.7 \%\right)(\mathrm{Ge}$ et al., 2016).

\section{$\mathrm{Cu}_{2} \mathrm{NiSnS}_{4}$}

Theoretical calculations claim that the substitution of $\mathrm{Zn}$ with $\mathrm{Ni}$ in CZTS could reduce the optical bandgap and potentially enhance electrical conductivity (Ghosh et al., 2014). These attractive features along with the sufficient abundance to annual production ratio provided by $\mathrm{Ni}$ make $\mathrm{Cu}_{2} \mathrm{NiSnS}_{4}$ (CNTS) worth to be considered for TW range PV applications. Currently, few works on CNTS are present in the literature, most of them reporting on thin films prepared by non-vacuum techniques, namely electrodeposition followed by sulfurization (Chen et al., 2016b; Yang et al., 2016), spray sandwich method (Dridi et al., 
2017; Bitri et al., 2018) and direct solution coating followed by sulfurization (Mokurala et al., 2017). As expected, the layer morphology was generally found to be strongly dependent on the substrate, the larger grain size being obtained on SLG due to the higher diffusion of $\mathrm{Na}$ from the substrate. Hall measurements showed that after sulfurization an increase in mobility and a decrease in resistivity occur (Mokurala et al., 2017), which were attributed to the passivation of defects (mainly $\mathrm{V}_{\mathrm{S}}$ ) and to the enhanced crystallization and in the CNTS thin films. The high absorption coefficient $\left(>10^{4} \mathrm{~cm}^{-1}\right)$ and the suitable optical bandgaps (i.e., 1.29-1.50 eV) generally obtained, along with some preliminary low resistivity values $[\cong 0.14 \Omega \mathrm{cm}$ (Mokurala et al., 2017)], suggest that cubic p-type CNTS thin films are promising for PV applications.

\section{$\mathrm{Cu}_{2} \mathrm{CoSnX}{ }_{4}, \mathrm{Cu}_{2} \mathrm{CdSnX}_{4}$, and $\mathrm{Ag}$ Related Quaternary Alloys ( $X=S$ and/or Se)}

Among the chalcogenide thin film absorbers based on less abundant elements (i.e., Co, Cd, and $\mathrm{Ag}$ ), most of the studies reported in the literature deals with $\mathrm{Cu}_{2} \mathrm{CdSnS}_{4}$ (CCdTS) $/ \mathrm{Cu}_{2} \mathrm{CdSn}(\mathrm{S}, \mathrm{Se})_{4}$ (CCdTSSe). In fact, despite the low abundance to annual production ratio provided by cadmium, the replacement of $\mathrm{Zn}$ by the bigger $\mathrm{Cd}$ atom leads to a reduced presence of detrimental $\mathrm{Zn}_{\mathrm{Cu}}$ antisite defects, which could enhance the conductivity (Hussain et al., 2016). Furthermore, the CCdTS bandgap is nearer than the CZTS one to the optimal value calculated by Shockley and Queisser (i.e., $1.34 \mathrm{eV}$ ) (Smets et al., 2016), which could potentially lead to more efficient PV devices. CCdTS, which more stable crystalline form is stannite, shows p-type conductivity related to the presence of $\mathrm{Cu}$ vacancies $\left(\mathrm{V}_{\mathrm{Cu}}\right)$ and/or $\mathrm{Cu}_{\mathrm{Cd}}$ antisites (Meng et al., 2015b). So far, CCdTS/CCdTSSe was mainly investigated in the form of nanocrystal (Fan et al., 2011; Ramasamy et al., 2013), while few works reported on the deposition of CCdTS/CCdTSSe thin films (Timmo et al., 2013; Nie et al., 2015; Zhao et al., 2015; Henry et al., 2016; Xu et al., 2016; Rouchdi et al., 2017) and in particular on CCdTS/CCdTSSe based PV devices (Timmo et al., 2013; Zhao et al., 2015). Among the latter, Timmo et al. prepared CCdTS monograin powders with $1.4 \mathrm{eV}$ bandgap from molten $\mathrm{CdI}_{2}$ or $\mathrm{KI}$ as flux materials sealed in quartz ampoules at $610^{\circ} \mathrm{C}$, reaching a $2.7 \%$ efficiency (Timmo et al., 2013). Zhao et al. (2015) reported on stannite CCdTSSe thin films prepared by a chemical solution approach, which showed large densely packed grains and suitable bandgap around $1 \mathrm{eV}$. Solar cell prototypes based on them showed a $3.1 \%$ efficiency. However, it should be remarked that $\mathrm{Cd}$ as well as many Cd based compound are toxic, making CCdTS/CCdTSSe not fully compatible with a green energy supply.

Finally, few literature works explored $\mathrm{Cu}_{2} \mathrm{CoSnS}_{4}$ and $\mathrm{Ag}$ related quaternary alloys as thin film PV absorbers, namely (Krishnaiah et al., 2015; Gershon et al., 2016a,b; Ghosh et al., 2016). Particularly attractive results were obtained for $\mathrm{Ag}_{2} \mathrm{ZnSnSe}_{4}$ (AZTSe) (Gershon et al., 2016a) and for $\left(\mathrm{Ag}_{\mathrm{x}} \mathrm{Cu}_{1-\mathrm{x}}\right)_{2} \mathrm{ZnSnSe}_{4}$ (Gershon et al., 2016b), which both showed efficiencies much higher than those reported in most of the previous paragraphs (see Table 1). Most probably, the reason is that the introduction of $\mathrm{Ag}$ in CZTSe was demonstrated to strongly reduce the band-tailing effect responsible for the $\mathrm{V}_{\mathrm{oc}}$ loss in kesterite thin film solar cells, which was discussed above in the CBTS section. Theoretical calculations (Chagarov et al., 2016) showed in fact that the formation energy of I-II antisite in AZTSe is significantly higher than in CZTSSe, which reduces the I-II antisite density by at least one order of magnitude. The band-tailing reduction is particularly relevant for pure-Ag materials (i.e., AZTSe), however Gershon et al. (2016b) showed that introducing only $10 \% \mathrm{Ag}$ in CZTSe allows to obtain a remarkable $10.2 \%$ efficiency. Despite a further optimization could potentially improve the performance of $\left(\mathrm{Ag}_{\mathrm{x}} \mathrm{Cu}_{1-\mathrm{x}}\right)_{2} \mathrm{ZnSnSe}_{4}$ based solar cells (Gershon et al., 2016b), silver is a further element under serious threat of extinction in the next 100 years (Harland et al., 2013), so most probably they will have a marginal role in the PV TW challenge.

\section{CONCLUSION AND PROSPECTS}

In this work, an extensive review of emerging sulfide/selenide materials with abundant and non-toxic elements is given. We are aware that the success of such emerging chalcogenide materials in the PV market will depend on many variables. Economic ones, including costs in $\$ / \mathrm{W}_{\mathrm{p}}$ and added value for both consumers and architects, and mainly scientific ones. As discussed here, although in the last few years the performance of emerging chalcogenide solar cells was significantly progressing, further improvements are needed to achieve the efficiency required for the practical use. In fact, of the many absorbers reviewed here, very few provided efficiencies over 5\%, as clearly summarized in Table $\mathbf{1 .}$ Some points were identified as critical: (a) the band-tailing effect responsible for the $\mathrm{V}_{\mathrm{oc}}$ loss in kesterite thin film solar cells has to be reduced. Up to now, this goal was encouragingly achieved in CBTS and mainly in $\left(\mathrm{Ag}_{\mathrm{x}} \mathrm{Cu}_{1-\mathrm{x}}\right)_{2} \mathrm{ZnSnSe} \mathrm{Z}_{4}$, however silver is under serious threat of extinction in the next 100 years, so further solutions must be explored; (b) the recombination has to be reduced, for example, by passivating the defects at the grain boundaries of the photo-absorber and at the photoabsorber/buffer interface; (c) the chemical composition and the manufacturing methods must be designed to avoid secondary phases and to manage the bulk defects; (d) the architecture of the device must be adapted to the characteristics of the absorber material. As we have reviewed, the research in the field is addressing these issues but is in a preliminary phase and many efforts are necessary to reach the goal. However, the technical and environmental profile of each new discussed material as well as the easy way of production are very promising. In fact, the recent advances in emerging solutions-based PV research have opened new paths, which could soon lead to some of these limitations being overcome. Moreover, several materials have been tested to optimize the device architecture and improve the interfaces. Lately, more and more research teams from different backgrounds are joining the efforts to make thin film photovoltaics based on chalcogenides available for commercialization. Because the limits of the discussed materials are many-sided, involving issues for chemistry, physics and engineering, in order to push ahead the research on new earthabundant thin film solar cells based on chalcogenides a more interdisciplinary research approach should be promoted. The final aim is to deliver versatile and efficient solar cells with 
clean and sustainable materials and that can hold a key role in energy production in the develop of that applications, such as building integration $\mathrm{PV}$, outdoor recreational, and low-power consumer electronics, where the conventional solar materials cannot be applied.

\section{AUTHOR CONTRIBUTIONS}

AL and VT made substantial contributions to the design of the work, to the reference acquisition, analysis or

\section{REFERENCES}

Anthony, J. W., Bideaux, R. A., Bladh, K. W., and Nichols, M. C. (eds.) (1990). Handbook of Mineralogy. Chantilly, VA: Mineralogical Society of America. Available online at: http://www.handbookofmineralogy.org

Bai, Y., Yeom, J., Yang, M., Cha, S.-H., Sun, K., and Kotov, N. A. (2013). Universal synthesis of single-phase pyrite FeS2 nanoparticles, nanowires, and nanosheets. J. Phys. Chem. C 117, 2567-2573. doi: 10.1021/jp3111106

Banu, S., Ahn, S. J., Eo, Y. J., Gwak, J., and Cho, A. (2017). Tin monosulfide (SnS) thin films grown by liquid-phase deposition. Solar Energy 145, 33-41. doi: 10.1016/j.solener.2016.12.013

Bhattacharyya, P. K., Dasgupta, S., Fukuoka, M., and Supriya, R. (1984). Geochemistry of braunite and associated phases in metamorphosed non-calcareous manganese ores of India. Mineral. Petrol. 87, 65-71. doi: 10.1007/BF00371403

Bi, Y., Yuan, Y., Exstrom, C. L., Darveau, S. A., and Huang, J. (2011). Air stable, photosensitive, phase pure iron pyrite nanocrystal thin films for photovoltaic application. Nano Lett. 11, 4953-4957. doi: 10.1021/nl202902z

Bitri, N., Dridi, S., Chaabouni, F., and Abaab, M. (2018). Studies on the electrical properties of $\mathrm{Cu} 2 \mathrm{NiSnS} 4$ thin films prepared by a simple chemical method. Mater. Lett. 213, 31-34. doi: 10.1016/j.matlet.2017.11.006

Bragagnolo, J. A., Barnett, A. M., Phillips, J. E., Hall, R. B., Rothwarf, A., and Meakin, J. D. (1980). The design and fabrication of thin-film CdS/Cu2S cells of 9.15-percent conversion efficiency. IEEE Transac. Electron Devices 27, 645-651. doi: 10.1109/T-ED.1980.19917

Burton, L. A., Colombara, D., Abellon, R. D., Grozema, F. C., Peter, L. M., Savenije, T. J., et al. (2013). Synthesis, characterization, and electronic structure of single-crystal SnS, Sn2S3, and SnS2. Chem. Mater. 25, 4908-4916. doi: $10.1021 / \mathrm{cm} 403046 \mathrm{~m}$

Cabán-Acevedo, M., Kaiser, N. S., English, C. R., Liang, D., Thompson, B. J., Chen, H.-E., et al. (2014). Ionization of high-density deep donor defect states explains the low photovoltage of iron pyrite single crystals. J. Am. Chem. Soc. 136, 17163-17179. doi: 10.1021/ja509142w

Chagarov, E., Sardashti, K., Kummel, A. C., Lee, Y. S., Haight, R., and Gershon, T. S. (2016). Ag2ZnSn(S,Se)4: a highly promising absorber for thin film photovoltaics. J. Chem. Phys. 144:104704. doi: 10.1063/1.4943270

Chatterjee, S., and Pal, A. J. (2017). A solution approach to p-type Cu2FeSnS4 thin-films and pn-junction solar cells: role of electron selective materials on their performance. Solar Energy Mater. Solar Cells 160, 233-240. doi: 10.1016/j.solmat.2016.10.037

Chen, G., Li, J., Chen, S., Huang, Z., Wu, M., Zhao, J., et al. (2017). Low cost oxidebased deposition of $\mathrm{Cu} 2 \mathrm{FeSnS} 4$ thin films for photovoltaic absorbers. Mater. Chem. Phys. 188, 95-99. doi: 10.1016/j.matchemphys.2016.12.024

Chen, H.-J., Fu, S.-W., Tsai, T.-C., and Shih, C.-F. (2016b). Quaternary Cu2NiSnS4 thin films as a solar material prepared through electrodeposition. Mater. Lett. 166, 215-218. doi: 10.1016/j.matlet.2015.12.082

Chen, L., Deng, H., Tao, J., Cao, H., Huang, L., Sun, L., et al. (2015b). Synthesis and characterization of earth-abundant $\mathrm{Cu} 2 \mathrm{MnSnS} 4$ thin films using a nontoxic solution based technique. RSC Adv. 5, 84295-84302. doi: 10.1039/C5RA1 $4595 \mathrm{C}$

Chen, L., Deng, H., Tao, J., Cao, H., Sun, L., Yang, P., et al. (2016a). Strategic improvement of Cu2MnSnS4 films by two distinct postannealing. Acta Mater. 109, 1-7. doi: 10.1016/j.actamat.2016.02.057 interpretation of data for the work and to the writing. SB made substantial contributions to the design of the work, critical analysis or interpretation of data for the work, revising it critically, provide approval for publication of the content.

\section{ACKNOWLEDGMENTS}

The authors thank Dr. S. Marchionna and RSE SpA for the fruitful collaboration on some of the described topics.

Chen, L., Deng, H., Tao, J., Zhou, W., Sun, L., Yue, F., et al. (2015a). Influence of annealing temperature on structural and optical properties of Cu2MnSnS4 thin films fabricated by sol-gel technique. J. Alloys Compounds 640, 23-28. doi: 10.1016/j.jallcom.2015.03.225

Chen, S., Walsh, A., Gong, X. G., and Wei, S. H. (2013). Classification of lattice defects in the kesterite $\mathrm{Cu} 2 \mathrm{ZnSnS} 4$ and $\mathrm{Cu} 2 \mathrm{ZnSnSe} 4$ earth-abundant solar cell absorbers. Adv. Mater. 25, 1522-1539. doi: 10.1002/adma.201203146

Congiu, M., Boratto, M. H., and Graeff, C. F. O. (2018). A synaptic electrochemical memristor based on the $\mathrm{Cu} 2+/ \mathrm{Zn} 2+$ cation exchange in $\mathrm{Zn}$ :CdS thin films. Chem. Select 3, 9794-9802. doi: 10.1002/slct.201801152

Congiu, M., Nunes-Neto, O., De Marco, M. L., Dini, D., and Graeff, C. F. O. (2016). $\mathrm{Cu} 2-\mathrm{xS}$ films as counter-electrodes for dye solar cells with ferrocene-based liquid electrolytes. Thin Solid Films 612, 22-28. doi: 10.1016/j.tsf.2016.05.033

Corathers, L. A. (2009). Mineral Commodity Summaries 2009: Manganese. Washington, DC: United States Geological Survey.

Cui, Y., Deng, R., Wang, G., and Pan, D. (2012). A general strategy for synthesis of quaternary semiconductor Cu2MSnS4 $(\mathrm{M}=\mathrm{Co} 2+, \mathrm{Fe} 2+, \mathrm{Ni} 2+, \mathrm{Mn} 2+)$ nanocrystals. J. Mater. Chem. 22:23136-23140. doi: 10.1039/c2jm33574c

Degrauw, A., Armstrong, R., Rahman, A. A., Ogle, J., and Whittaker-Brooks, L. (2017). Catalytic growth of vertically aligned SnS/SnS 2 p-n heterojunctions. Mater. Res. Expr. 4:094002. doi: 10.1088/2053-1591/aa8a37

Dridi, S., Bitri, N., and Abaab, M. (2017). Synthesis of quaternary Cu2NiSnS4 thin films as a solar energy material prepared through «spray» technique technique. Mater. Lett. 204, 61-64. doi: 10.1016/j.matlet.2017.06.028

Eow, J. S. (2002). Recovery of sulfur from sour acid gas: a review of the technology. Environ. Prog. 21, 143-162. doi: 10.1002/ep.670210312

Evstigneeva, T. L., and Kabalov, Y. K. (2001). Crystal structure of the cubic modification of Cu2FeSnS4. Kristallografiya 46, 418-422. doi: 10.1134/1.1376461

Fan, F., Yu, B., Wang, Y., Zhu, Y., Liu, X., Yu, S., et al. (2011). Colloidal synthesis of $\mathrm{Cu} 2 \mathrm{CdSnSe} 4$ nanocrystals and hot-pressing to enhance the thermoelectric figure-of-merit. J. Am. Chem. Soc. 133, 15910-15913. doi: 10.1021/ja207159j

Fraunhofer ISE, 2017 Fraunhofer ISE (2017). Photovoltaics Report. Technical Report. Freiburg: Fraunhofer ISE.

Gautier, C., Breton, G., Nouaoura, M., Cambon, M., Charar, S., and Averous, M. (1998). Sulfide films on PbSe thin layer grown by MBE. Thin Solid Films 315, 118-122. doi: 10.1016/S0040-6090(97)00785-2

Ge, J., Yu, Y., and Yan, Y. (2016). Earth-abundant BaCu2Sn(SexS1-x)4 (x $\approx$ 0.83) thin-film for solar energy conversion. ACS Energy Lett. 1, 583-588. doi: 10.1021/acsenergylett.6b00324

Gedi, S., Minna Reddy, V. R., Pejjai, B., Jeon, C.-W., Park, C., and Ramakrishna Reddy, K. T. (2016). A facile inexpensive route for SnS thin film solar cells with SnS2 buffer. Appl. Surf. Sci. 372, 116-124. doi: 10.1016/j.apsusc.2016.03.032

Gershon, T., Lee, Y. S., Antunez, P., Mankad, R., Singh, S., Bishop, D., et al. (2016b). Photovoltaic materials and devices based on the alloyed kesterite absorber (AgxCu1-x)2ZnSnSe4. Adv. Energy Mater. 6:1502468. doi: 10.1002/aenm.201502468

Gershon, T., Sardashti, K., Gunawan, O., Mankad, R., Singh, S., Lee, Y. S., et al. (2016a). Photovoltaic device with over 5\% efficiency based on an n-type Ag2ZnSnSe4 absorber. Adv. Energy Mater. 6:1601182. doi: 10.1002/aenm.201601182

Ghosh, A., Chaudhary, D. K., Biswas, A., Thangavel, R., and Udayabhanu, G. (2016). Solution processed Cu2XSnS4 (X = Fe, Co, Ni) photo-electrochemical 
and thin film solar cells on vertically grown $\mathrm{ZnO}$ nanorod arrays. RSC Adv. 6, 115204-115212. doi: 10.1039/C6RA24149B

Ghosh, A., Thangavel, R., and Rajagopalan, M. (2014). First-principles study of structural stability and optical properties of Cu2XSnY4 (X = Fe, Co, Ni; Y $=\mathrm{S}, \mathrm{Se}$ ) for photovoltaic applications. Energy and Environ. Focus 3, 142-151. doi: 10.1166/eef.2014.1080

Gokmen, T., Gunawan, O., Todorov, T. K., and Mitzi, D. B. (2013). Band tailing and efficiency limitation in kesterite solar cells. Appl. Phys. Lett. 103:103506. doi: $10.1063 / 1.4820250$

Guan, H., Shen, H., Jiao, B., and Wang, X. (2014). Structural and optical properties of $\mathrm{Cu} 2 \mathrm{FeSnS} 4$ thin film synthesized via a simple chemical method. Mater. Sci. Semiconduct. Process. 25, 159-162. doi: 10.1016/j.mssp.2013.10.021

Harland, C., Nassimbeni, G., and Schneller, E. (eds.). (2013). The SAGE Handbook of Strategic Supply Management. London: SAGE Publishing.

Henry, J., Prema, P., Padiyan, D. P., Mohanraj, K., and Sivakumar, G. (2016). Shape-dependent optoelectrical investigation of $\mathrm{Cu} 2+\mathrm{xCd} 1-\mathrm{xSnS} 4$ thin-films for solar cell applications. New J. Chem. 40, 2609-2618. doi: $10.1039 /$ C5NJ03154K

Hoffert, M. I., Caldeira, K., Jain, A. K., Haites, E. F., Harvey, L. D. D., Potter, S. D., et al. (1998). Energy implications of future stabilization of atmospheric CO2 content, Nature 395, 881-884. doi: 10.1038/27638

Huang, S., He, Q., Chen, W., Zai, J., Qiao, Q., and Qian, X. (2015). 3D hierarchical FeSe2 microspheres: Controlled synthesis and applications in dye-sensitized solar cells. Nano Energy 15, 205-215. doi: 10.1016/j.nanoen.2015.04.027

Hussain, S., Murtaza, G., Khan, S. H., Khan, A., Ali, M. A., Faizan, M., et al. (2016). First principles study of structural, optoelectronic and thermoelectric properties of Cu2CdSnX4 (X = S, Se, Te) chalcogenides. Mater. Res. Bull. 79, 73-83. doi: 10.1016/j.materresbull.2016.03.001

Ito K. (ed.). (2014). Copper Zinc Tin Sulphide-Based Thin Film Solar Cells.

Jeong, G., Kim, J., Gunawan, O., Pae, S. R., Kim, S. H., Song, J. Y., et al. (2017). Preparation of single-phase SnSe thin-films and modification of electrical properties via stoichiometry control for photovoltaic application. J. Alloys Compounds 722, 474-481. doi: 10.1016/j.jallcom.2017.06.094

Jiang, F., Ozaki, C., Gunawan, G., Harada, T., Tang, Z., Minemoto, T., et al. (2016). Effect of indium doping on surface optoelectrical properties of Cu2ZnSnS4 photoabsorber and interfacial/photovoltaic performance of cadmium free In2S3/Cu2ZnSnS4 heterojunction thin film solar cell. Chem. Mater. 28, 3283-3291. doi: 10.1021/acs.chemmater.5b04984

Jiang, T., and Ozin, G. A. (1998). New directions in tin sulfide materials chemistry. J. Mater. Chem. 8, 1099-1108. doi: 10.1039/a709054d

Karthick Kannan, P., Late, D. J., Morgan, H., and Rout, C. S. (2015). Recent developments in 2D layered inorganic nanomaterials for sensing. Nanoscale 7, 13293-13312. doi: 10.1039/C5NR03633J

Kasper, A. C., Berselli, G. B. T., Freitas, B. D., Tenório, J. A. S., Bernardes, A. M., and Veit, H. M. (2011). Printed wiring boards for mobile phones: characterization and recycling of copper. Waste Manage. 31, 2536-2545. doi: 10.1016/j.wasman.2011.08.013

Kevin, P., Malik, M. A., and O'Brien, P. (2015). The AACVD of Cu2FeSn(SxSe1x)4: potential environmentally benign solar cell materials. New J. Chem. 39, 7046-7053. doi: 10.1039/C5NJ01198A

Khadka, D. B., and Kim, J. (2015). Structural, optical and electrical properties of $\mathrm{Cu} 2 \mathrm{FeSnX} 4(\mathrm{X}=\mathrm{S}, \mathrm{Se})$ thin films prepared by chemical spray pyrolysis. J. Alloys Compounds 638, 103-108. doi: 10.1016/j.jallcom.2015.03.053

Kilic, B., and Turkdogan, S. (2017). Fabrication of dye-sensitized solar cells using graphene sandwiched $3 \mathrm{D}-\mathrm{ZnO}$ nanostructures based photoanode and Pt-free pyrite counter electrode. Mater. Lett. 193, 195-198. doi: 10.1016/j.matlet.2017.01.128

Kim, J., Kim, J., Yoon, S., Kang, J.-y., Jeon, C.-W., and Jo, W. (2018). Single phase formation of SnS competing with SnS2 and Sn2S3 for photovoltaic applications: optoelectronic characteristics of thin-film surfaces and interfaces. J. Phys. Chem. C 122, 3523-3532. doi: 10.1021/acs.jpcc.8b 00179

Kresse, R., Baudis, U., Jäger, P., Riechers, H. H., Wagner, H., Winkler, J., et al. (2007). "Barium and barium compounds," in Ullmann's Encyclopedia of Industrial Chemistry (Weinheim: Wiley-VCH). doi: 10.1002/14356007.a03_325.pub2

Krishnaiah, M., Bhargava, P., and Mallick, S. (2015). Low-temperature synthesis of Cu2CoSnS4 nanoparticles by thermal decomposition of metal precursors and study of its structural, optical and electrical properties for photovoltaic application. RSC Adv. 5, 96928-96933. doi: 10.1039/C5RA18679J

Kuck, P. H. (2012). Mineral Commodity Summaries 2012: Nickel. Reston, VA: United States Geological Survey.

Kumar, M., Dubey, A., Adhikari, N., Venkatesan, S., and Qiao, Q. (2015). Strategic review of secondary phases, defects and defect-complexes in kesterite CZTS-Se solar cells. Energy Environ. Sci. 8, 3134-3159. doi: 10.1039/C5EE0 $2153 \mathrm{G}$

Le Donne, A., Marchionna, S., Acciarri, M., Cernuschi, F., and Binetti, S. (2017). Relevant efficiency enhancement of emerging Cu2MnSnS4 thin film solar cells by low temperature annealing. Solar Energy 149, 125-131. doi: 10.1016/j.solener.2017.03.087

Lefebvre, I., Szymanski, M. A., Olivier-Fourcade, J., and Jumas, J. C. (1998). Electronic structure of tin monochalcogenides from SnO to SnTe. Phys. Rev. B 58, 1896-1906. doi: 10.1103/PhysRevB.58.1896

Lei, H., Fang, G., Cheng, F., Ke, W., Qin, P., Song, Z., et al. (2014). Enhanced efficiency in organic solar cells via in situ fabricated p-type copper sulfide as the hole transporting layer. Solar Energy Mater. Solar Cells 128, 77-84. doi: 10.1016/j.solmat.2014.05.021

Li, L., Zhu, P., Peng, S., Srinivasan, M., Yan, Q., Nair, A. S., et al. (2014). Controlled growth of $\mathrm{CuS}$ on electrospun carbon nanofibers as an efficient counter electrode for quantum dot-sensitized solar cells. J. Phys. Chem. C 118, 16526-16535. doi: 10.1021/jp4117529

Liang, X., Guo, P., Wang, G., Deng, R., Pan, D., and Wei, X. (2012). Dilute magnetic semiconductor $\mathrm{Cu} 2 \mathrm{MnSnS} 4$ nanocrystals with a novel zincblende and wurtzite structure. RSC Adv. 2, 5044-5046. doi: 10.1039/c2ra20198d

Liu, G., Schulmeyer, T., Brötz, J., Klein, A., and Jaegermann, W. (2003). Interface properties and band alignment of Cu2S/CdS thin film solar cells. Thin Solid Films 431-432, 477-482. doi: 10.1016/S0040-6090(03)00190-1

Liu, X., Feng, Y., Cui, H., Liu, F., Hao, X., Conibeer, G., et al. (2016). The current status and future prospects of kesterite solar cells: a brief review. Prog. Photovolt Res. Appl. 24, 879-898. doi: 10.1002/pip.2741

Loferski, J. J., Shewchun, J., Mittleman, S. D., DeMeo, E. A., Arnott, R., Hwang, H. L., et al. (1979). Cathodoluminescence characteristics of CuxS films produced by different methods. Solar Energy Mater. 1, 157-169. doi: 10.1016/0165-1633(79)90064-9

Mani, P., Manikandan, K., Ramya, A. J., Seelan, A. I., Zahirullah, S. S., Hameed, M. S., et al. (2014). Influence of molar concentrations on optical properties of copper sulphide thin films by SILAR method. Int. J. ChemTech Res. 6 , 3573-3578.

Marchionna, S., Le Donne, A., Merlini, M., Binetti, S., Acciarri, M., and Cernuschi, F. (2017). Growth of Cu2MnSnS4 PV absorbers by sulfurization of evaporated precursors. J. Alloys Compounds 693, 95-102. doi: 10.1016/j.jallcom.2016.09.176

Meng, L., Li, Y., Yao, B., Ding, Z., and Yang, G. (2015b). Mechanism of effect of intrinsic defects on electrical and optical properties of Cu2CdSnS4: an experimental and first-principles study. J. Phys. D Appl. Phys. 48:445105. doi: 10.1088/0022-3727/48/44/445105

Meng, X., Deng, H., He, J., Sun, L., Yang, P., and Chu, J. (2015a). Synthesis, structure, optics and electrical properties of $\mathrm{Cu} 2 \mathrm{FeSnS} 4$ thin film by sputtering metallic precursor combined with rapid thermal annealing sulfurization process. Mater. Lett. 151, 61-63. doi: 10.1016/j.matlet.2015.03.046

Meng, X., Deng, H., Tao, J., Cao, H., Li, X., Sun, L., et al. (2016). Heating rate tuning in structure, morphology and electricity properties of $\mathrm{Cu} 2 \mathrm{FeSnS} 4$ thin films prepared by sulfurization of metallic precursors. J. Alloys Compounds 680, 446-451. doi: 10.1016/j.jallcom.2016.04.166

Miao, X., Chen, R., and Cheng, W. (2017). Synthesis and characterization of $\mathrm{Cu} 2 \mathrm{FeSnS} 4$ thin films prepared by electrochemical deposition. Mater. Lett. 193, 183-186. doi: 10.1016/j.matlet.2017.01.099

Minnam Reddy, V. R., Lindwall, G., Pejjai, B., Gedi, S., Reddy Kotte, T. R., Sugiyama, M., et al. (2018). $\alpha$-SnSe thin film solar cells produced by selenization of magnetron sputtered tin precursors. Solar Energy Mater. Solar Cells 176, 251-258. doi: 10.1016/j.solmat.2017.12.003

Moitra, K., and Deb, S. (1983). Degradation of the performance of Cu2S/CdS solar cells due to a two-way solid state diffusion process. Solar Cells 9, 215-228. doi: 10.1016/0379-6787(83)90048-0

Mokurala, K., Mallick, S., Bhargava, P., Siol, S., Klein, T. R., and van Hest, M. F. A. M. (2017). Influence of dipping cycles on physical, 
optical, and electrical properties of Cu2NiSnS4: direct solution dip coating for photovoltaic applications. J. Alloys Compounds 725, 510-518. doi: 10.1016/j.jallcom.2017.07.188

Morrish, R., Silverstein, R., and Wolden, C. A. (2012). Synthesis of stoichiometric FeS2 through plasma-assisted sulfurization of Fe2O3 nanorods. J. Am. Chem. Soc. 134, 17854-17857. doi: 10.1021/ja307412e

Mousavi-Kamazani, M., Zarghami, Z., and Salavati-Niasari, M. (2016). Facile and novel chemical synthesis, characterization, and formation mechanism of copper sulfide (Cu2S, Cu2S/CuS, CuS) nanostructures for increasing the efficiency of solar cells. J. Phys. Chem. C 120 2096-2108. doi: 10.1021/acs.jpcc.5b11566

Munson, R. A., and De Sorbo, W., Kouvel, J. S. (1967). Electrical magnetic and superconducting properties of copper disulfide. J. Chem. Phys. 47:1769. doi: $10.1063 / 1.1712162$

Murakami, M., Ohishi, Y., Hirao, N., and Hirose, K. (2012). A perovskitic lower mantle inferred from high-pressure, high-temperature sound velocity data. Nature 485, 90-94. doi: 10.1038/nature11004

Nair, M. T. S., Laura, G., and Nair, P. K. (1998). Conversion of chemically deposited $\mathrm{CuS}$ thin films to Cu1.8S and Cu1.96S by annealing. Semiconduc. Sci. Technol. 13:1164. doi: 10.1088/0268-1242/13/10/019

Neuschitzer, M., Sanchez, Y., Olar, T., Thersleff, T., Lopez-Marino, S., Oliva, F., et al. (2015). Complex surface chemistry of kesterites: $\mathrm{Cu} / \mathrm{Zn}$ reordering after low temperature postdeposition annealing and its role in high performance devices. Chem. Mater. 27, 5279-5287. doi: 10.1021/acs.chemmater.5b01473

Nickel Institute. Data from the Nickel Institute. Canada, Belgium, United States, Japan, China. Available online at: https://www.nickelinstitute.org (accessed April 2019)

Nie, L., Liu, S., Chai, Y., and Yuan, R. (2015). Spray pyrolysis deposition and photoresponse of Cu2CdSnS4 thin-films. J. Analy. Appl. Pyrolysis 112, 363-368. doi: 10.1016/j.jaap.2014.12.020

Niemegeers, A., and Burgelman, M. (1986). Effect of ionic electromigration on Cu2- $\alpha$ S/CdS solar cell. J. Appl. Phys. 59, 1360-1365. doi: 10.1063/1.3 37031

Page, M., Niitsoo, O., Itzhaik, Y., Cahen, D., and Hodes, G. (2009). Copper sulfide as a light absorber in wet-chemical synthesized extremely thin absorber (ETA) solar cells. Energy Environ. Sci. 2, 220-223. doi: 10.1039/B813740D

Pałosz, B., Steurer, W., and Schulz, H. (1990). Refinement of SnS2 polytypes $2 \mathrm{H}, 4 \mathrm{H}$ and 18R. Acta Crystallogr. Section B 46, 449-455. doi: $10.1107 /$ S0108768189012577

Patil, S. S., Desai, N. D., Kharade, S. D., Joshi, M. P., Khot, K. V., Mane, R. M., et al. (2018). Single step fabrication of $\mathrm{CuS}$ thin film via hydrothermal route for solar cell application. AIP Conf. Proc. 1989:020029. doi: 10.1063/1.50 47705

Petrović, M., Gilić, M., Cirković, J., Romčević, M., Romčević, N., Trajić, J., et al. (2017). Optical properties of CuSe thin films - band gap determination. Sci. Sinter. 49, 167-174. doi: 10.2298/SOS1702167P

Podsiadlo, S., Bialoglowski, M., Fadaghi, M., Gebicki, W., Jastrzebski, C., Zero, E., et al. (2015). Synthesis of magnetic doped kesterite single crystals. Cryst. Res. Technol. 50, 690-694. doi: 10.1002/crat.201400435

Prabhakar, R. R., Zhenghua, S., Xin, Z., Baikie, T., Shin, L., Shukla, S., et al. (2016). Photovoltaic effect in earth abundant solution processed Cu2MnSnS4 and Cu2MnSn(S,Se)4 thin-films. Sol. Energy Mater. Sol. Cells 157, 867-873. doi: 10.1016/j.solmat.2016.07.006

Prabukanthan, P., Thamaraiselvi, S., and Harichandran, G. (2017). Single step electrochemical deposition of p-type undoped and $\mathrm{Co} 2+$ doped FeS2 thin films and performance in heterojunction solid solar cells. J. Electrochem. Soc. 164, D581-D589. doi: 10.1149/2.0991709jes

Price, L. S., Parkin, I. P., Hardy, A. M. E., Clark, R. J. H., Hibbert, T. G., and Molloy, K. C. (1999). Atmospheric pressure chemical vapor deposition of tin sulfides (SnS, Sn2S3, and SnS2) on glass. Chem. Mater. 11, 1792-1799. doi: $10.1021 / \mathrm{cm} 990005 z$

Puthussery, J., Seefeld, S., Berry, N., Gibbs, M., and Law, M. (2011). Colloidal iron pyrite (FeS2) nanocrystal inks for thin-film photovoltaics. J. Am. Chem. Soc. 133, 716-719. doi: 10.1021/ja1096368

Quintero, M., Barreto, A., Grima, P., Tovar, R., Quintero, E., Porras, G. S., et al. (1999). Crystallographic properties of I2-Fe-IV-VI4 magnetic semiconductor compounds. Mater. Res. Bull. 34, 2263-2270. doi: $10.1016 /$ S0025-5408(00)00166-5
Qurashi, A. (2014). Metal Chalcogenide Nanostructures for Renewable Energy Applications. Beverly, MA: Wiley; Scrivener Publishing.

Raadik, T., Grossberg, M., Raudoja, J., Traksmaa, R., and Krustok, J. (2013). Temperature-dependent photoreflectance of SnS crystals. J. Phys. Chem. Solids 74, 1683-1685. doi: 10.1016/j.jpcs.2013.06.002

Ramasamy, K., Zhang, Z., Bennett, R. D., and Gupta, A. (2013). Synthesis, photoconductivity and self-assembly of wurtzite phase Cu2CdxZn1-xSnS4 nanorods. RSC Adv. 3, 1186-1193. doi: 10.1039/C2RA22503D

Rao, H., Sun, W., Ye, S., Yan, W., Li, Y., Peng, H., et al. (2016). Solutionprocessed CuS NPs as an inorganic hole-selective contact material for inverted planar perovskite solar cells. ACS Appl. Mater. Interfaces 8, 7800-7805. doi: 10.1021/acsami.5b12776

Razykov, T. M., Boltaev, G. S., Bosio, A., Ergashev, B., Kouchkarov, K. M., Mamarasulov, N. K., et al. (2018). Characterisation of SnSe thin films fabricated by chemical molecular beam deposition for use in thin film solar cells. Solar Energy 159, 834-840. doi: 10.1016/j.solener.2017.11.053

Remus, R., Aguado Monsonet, M. A., Roudier, S., and Delgado Sancho, L. (2013). Best Available Techniques (BAT) Reference Document for Iron and Steel Production, Industrial Emissions Directive 2010/75/EU (Integrated Pollution Prevention and Control). JRC Reference Report, Luxembourg: Publications Office of the European Union.

REN21 (2018). REN21 Renewables Global Status Report. Paris: REN21 Secretariat.

Rimmington, H. P. B., Balchin, A. A., and Tanner, B. K. (1972). Nearly perfect single crystals of layer compounds grown by iodine vapour-transport techniques. J. Crystal Growth 15, 51-56. doi: 10.1016/0022-0248(72)90319-3

Rouchdi, M., Salmani, E., Hassanain, N., and Mzerd, A. (2017). Effect of deposition time on structural and physical properties of $\mathrm{Cu} 2 \mathrm{CdSnS4} 4$ thin-films prepared by spray pyrolysis technique: experimental and ab initio study. Opt. Quant. Electron. 49, 1-12. doi: 10.1007/s11082-017-1005-8

Sabah, F. A., Ahmed, N. M., Hassan, Z., and Rasheed, H. S. (2015). CuS P-type thin film characteristics for different copper to Sulphur molar ratios for light emitting diode application. J. Sci. Res. Dev. 13, 95-99.

Sanchez Ranjel, H. S., Carrillo Castillo, A., Hernandeez Paz, J. F., Frias Mancilla, R., Camacho Montes, H., Garcia Casillas, P. E., et al. (2015). Synthesis of copper sulfide (CuS) thin films by a solid-vapor reaction. Chalcogenide lett. $12,381-387$.

Sanchez-Juarez, A., Tiburcio-Silver, A., and Ortiz, A. (2005). Fabrication of SnS2/SnS heterojunction thin Film diodes by plasma-enhanced chemical vapor deposition. Thin Solid Films 480, 452-456. doi: 10.1016/j.tsf.2004.11.012

Santoni, A., Biccari, F., Malerba, C., Valentini, M., Chierchia, R., and Mittiga, A. (2013). Valence band offset at the CdS/Cu2ZnSnS4 interface probed by x-ray photoelectron spectroscopy. J. Phys. D. Appl. Phys. 46, 175101. doi: 10.1088/0022-3727/46/17/175101

Scott, K., Chen, X., Atkinson, J. W., Todd, M., and Armstrong, R. D. (1997). Electrochemical recycling of tin, lead and copper from stripping solution in the manufacture of circuit boards. Resour. Conserv. Recycl. 20, 43-55. doi: 10.1016/S0921-3449(97)01198-1

Shin, D., Saparov, B., Zhu, T., Huhn, W. P., Blum, V., and Mitzi, D. B. (2016). $\mathrm{BaCu} 2 \mathrm{Sn}(\mathrm{S}, \mathrm{Se}) 4$ : earth-abundant chalcogenides for thin-film photovoltaics. Chem. Mater. 28, 4771-4780. doi: 10.1021/acs.chemmater.6b01832

Shin, D., Zhu, T., Huang, X., Gunawan, O., Blum, V., and Mitzi, D. B. (2017). Earth-abundant chalcogenide photovoltaic devices with over 5\% efficiency based on a Cu2BaSn(S,Se)4 absorber. Adv. Mater. 29:1606945. doi: 10.1002/adma.201606945

Sinsermsuksakul, P., Sun, L., Lee, S. W., Park, H. H., Kim, S. B., Yang, C., et al. (2014). Overcoming efficiency limitations of SnS-based solar cells. Adv. Energy Mater. 4:1400496. doi: 10.1002/aenm.201400496

Smets, A., Jäger, K., Isabella, O., Van Swaaij, R., and Zeman, M. (2016). Solar Energy: The Physics and Engineering of Photovoltaic Conversion, Technologies and Systems. Cambridge: UIT Cambridge LTd.

Sun, K., Yan, C., Liu, F., Huang, J., Zhou, F., Stride, J. A., et al. (2016). Over 9\% efficient kesterite $\mathrm{Cu} 2 \mathrm{ZnSnS} 4$ solar cell fabricated by using $\mathrm{Zn1-xCdxS}$ buffer layer. Adv. Energy Mater. 6:1600046. doi: 10.1002/aenm.201600046

Tao, C. S., Jiang, J., and Tao, M. (2011). Natural resource limitations to terawatt-scale solar cells. Solar Energy Mater Solar Cells 95, 3176-3180. doi: 10.1016/j.solmat.2011.06.013

Tao, M. (2014). Terawatt Solar Photovoltaics-Roadblocks and Opportunities. London; Heidelberg; New York, NY; Dordrecht: Springer. 
Thangaraju, B., and Kaliannan, P. (2000). Spray pyrolytic deposition and characterization of SnS and SnS2 thin films. J. Phys. D Appl. Phys. 33, 1054-1059. doi: 10.1088/0022-3727/33/9/304

Timmo, K., Kauk-Kuusik, M., Altosaar, M., Raudoja, J., Raadik, T., Grossberg, M., et al. (2013). "Novel Cu2CdSnS4 and Cu2ZnGeSe4 absorber materials for monograin layer solar cell applications," in Proceedings of the 28th European Photovoltaic Solar Energy Conference and Exhibition (Paris), 2385-2388.

Ul Haq, B., AlFaify, S., Ahmed, R., Butt, F. K., Laref, A., and Shkir, M. (2018). Exploring single-layered SnSe honeycomb polymorphs for optoelectronic and photovoltaic applications. Phys. Rev. B 97:075438. doi: 10.1103/PhysRevB.97.075438

United Nations Ocean Economics and Technology Office. (ed.). (1978). “Technology Branch, United Nations," in Manganese Nodules: Dimensions and Perspectives (London; Heidelberg; New York, NY; Dordrecht: Springer).

USGS. Commodity Statistics and Information. U.S. Geological Survey National Minerals Information Center. Available online at: https://minerals.usgs.gov/ minerals/pubs/commodity/ (accessed April 2019).

Vanalakara, S. A., Patil, P. S., and Kim, J. H. (2018). Recent advances in synthesis of Cu2FeSnS4 materials for solar cell applications: a review. Solar Energy Mater. Solar Cells 182, 204-219. doi: 10.1016/j.solmat.2018. 03.021

Wadia, C., Alivisatos, A. P., and Kammen, D. M. (2009). Materials availability expands the opportunity for large-scale photovoltaics deployment. Environ. Sci. Technol. 43, 2072-2077. doi: 10.1021/es8019534

Wang, W., Winkler, M. T., Gunawan, O., Gokmen, T., Todorov, T. K., Zhu, Y., et al. (2014). Device characteristics of CZTSSe thin-film solar cells with 12.6\% efficiency. Adv. Energy Mater. 4:1301465. doi: 10.1002/aenm.2013 01465

Wang, X., Liu, T., Guan, H., Yu, F., and Hou, H. (2015). A comparative study of $\mathrm{Cu} 2 \mathrm{MnSnS} 4$ thin films synthesized via different chemical methods. Optoelectr. Adv. Mat. Rapid Comm. 9, 1190-1193.

Wang, X., Zhao, X., Hu, C., Zhang, Y., Song, B., Zhang, L., et al. (2016). Large lateral photovoltaic effect with ultrafast relaxation time in SnSe/Si junction. Appl. Phys. Lett. 109:023502. doi: 10.1063/1.4955480

WebElements. Abundance in Earth's Crust From WebElements. com. Available online at: https://www.webelements.com/periodicity/abund_crust/ (accessed April 2019).

Wu, Y., Wadia, C., Ma, W., Sadtler, B., and Alivisatos, A. P. (2008). Synthesis and photovoltaic application of copper(I) sulfide nanocrystals. Nano Lett 8 2551-2555. doi: 10.1021/nl801817d

Xiao, Z., Meng, W., Li, J. V., and Yan, Y. (2017). Distant-atom mutation for better earth-abundant light absorbers: a case study of Cu2BaSnSe4. ACS Energy Lett. 2, 29-35. doi: 10.1021/acsenergylett.6b00577
Xu, N., Li, P., Hao, Y., Wang, X., and Meng, L. (2016). Effect of sputtering power on $\mathrm{Cd} / \mathrm{Zn}$ atomic ratio and optical properties of $\mathrm{Cu} 2 \mathrm{ZnxCd} 1-\mathrm{xSnS} 4$ thin-films deposited by magnetron sputtering: an experimental and first-principle study. Chem. Phys. Lett. 660, 132-135. doi: 10.1016/j.cplett.2016.08.014

Yang, C. L., Chen, Y. H., Lin, M., Wu, S. L., Li, L., Liu, W. C., et al. (2016). Structural, optical and magnetic properties of Cu2NiSnS4 thin films deposited by facile one-step electrodeposition. Mater. Lett. 166, 101-104. doi: 10.1016/j.matlet.2015.12.054

Ye, M., Wen, X., Zhang, N., Guo, W., Liu, X., and Lin, C. (2015). In situ growth of $\mathrm{CuS}$ and $\mathrm{Cu1} .8 \mathrm{~S}$ nanosheet arrays as efficient counter electrodes for quantum dot-sensitized solar cells. J. Mater. Chem. A 3, 9595-9600. doi: 10.1039/C5TA00390C

Yu, J., Deng, H., Tao, J., Chen, L., Cao, H., Sun, L., et al. (2017). Synthesis of $\mathrm{Cu} 2 \mathrm{MnSnS} 4$ thin-film deposited on seeded fluorine doped tin oxide substrate via a green and low-cost electrodeposition method. Mater. Lett. 191, 186-188. doi: 10.1016/j.matlet.2016.12.067

Yu, L., Lany, S., Kykyneshi, R., Jieratum, V., Ravichandran, R., Pelatt, B., et al. (2011). Iron chalcogenide photovoltaic absorbers. Adv. Energy Mater. 1, 748-753. doi: 10.1002/aenm.201100351

Zhang, W., and Cheng, C. Y. (2007). Manganese metallurgy review. Part I: leaching of ores/secondary materials and recovery of electrolytic/chemical manganese dioxide. Hydrometallurgy 89, 137-159. doi: 10.1016/j.hydromet.2007.08.010

Zhang, X., Guo, W., and Pan, C. (2016b). Transparent conducting oxide-free and Pt-free flexible dye-sensitized solar cells employing CuS-nanosheet networks as counter electrodes. J. Mater. Chem. A 4, 6569-6576. doi: 10.1039/C6TA01353H

Zhang, X., Liu, X., Zhang, Y., Bao, R., Peng, D., Li, T., et al. (2016a). Rational design of an ITO/CuS nanosheet network composite film as a counter electrode for flexible dye sensitized solar cells. J. Mater. Chem. C 4, 8130-8134. doi: 10.1039/C6TC02610A

Zhao, W., Wang, G., Tian, Q., Huang, L., Gao, S., and Pan, D. (2015). Solutionprocessed Cu2CdSn(S,Se)4 thin film solar cells. Solar Energy Mater. Solar Cells 133, 15-20. doi: 10.1016/j.solmat.2014.10.040

Conflict of Interest Statement: The authors declare that the research was conducted in the absence of any commercial or financial relationships that could be construed as a potential conflict of interest.

Copyright (c) 2019 Le Donne, Trifiletti and Binetti. This is an open-access article distributed under the terms of the Creative Commons Attribution License (CC BY). The use, distribution or reproduction in other forums is permitted, provided the original author(s) and the copyright owner(s) are credited and that the original publication in this journal is cited, in accordance with accepted academic practice. No use, distribution or reproduction is permitted which does not comply with these terms. 